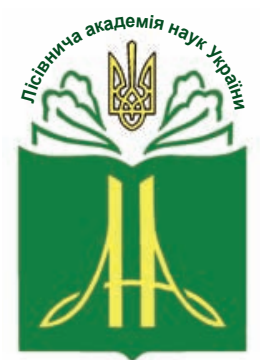

Forestry Academy of Sciences of Ukraine
Наукові праці Лісівничої академії наук України Proceedings of the Forestry Academy of Sciences of Ukraine http://fasu.nltu.edu.ua https://doi.org/10.15421/412104

Article received 2021.01.21

Article accepted 2021.06.10
ISSN 1991-606X print

ISSN 2616-5015 online

(a) $\triangle$ Correspondence author

Vasyl Losyuk

losyuk@i.ua
Druzhby str., 84, Kosiv, 78600, Ukraine

УДК $630 * 228.8$

\title{
Стан і структура природних ялинових лісів Покутських Карпат
}

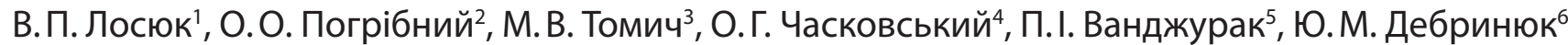

Природні ялинові ліси Покутських Карпат сформувались на площі 8,2 тис. га, щзо становить близько 21\% площуі всіх лісів досліджуваного регіону, займаючи висотні місиеположення понад 900 м н.р.м. Під час здійснення робіт використано новітні GIS-методи дослідження, багатоканальні супутникові знімки Lansat та інтерактивну карту поширення ялинових пралісів і квазіпралісів у Карпатському регіоні.

Основні таксачійні характеристики та динаміку сукцесій ялинових лісостанів проаналізовано на прикладі постійної пробної площчі (ППП), закладеної в ялиновому природному лісі, за своӥми характеристиками дуже близького до пралісового угруповання, в умовах вологої чистої високогірної сусмеречини. Польові дослідження здійснено з 2010 р. з п'ятирічним інтервалом відповідно до методики екологічного моніторингу II рівня за програмою «ICP-Forest». Лісостан на ППП представлений корінним триярусним різновіковим чистим ялиновим деревостаном, який характеризується високою кількістю дерев, високим запасом стовбурової деревини, вагомим запасом мертвої лежачої деревини, високою кількістю благонадійного підросту різних висотних груп, близькою до середньої життєвістю дерев, високою їх товарністю, незначним антропогенним впливом. Розташування дерев у деревостані має груповий характер, зімкнутість крон змінюється в межах 0,8-1,0. Трав'яне вкриття представлено більш ніж 30 видами із загальним проективним вкриттям 85\%. При и̧ьому спостережено прочеси трансформації рослинного покриву.

Наведено розташування та площу ялинових пралісів і квазіпралісів Покутських Карпат, які є еталонами природних екосистем і дають можливість прогнозувати розвиток природних ялинових лісів.

Ключові слова: Українські Карпати; деревостан; мертва лежача деревина; природне поновлення; трав 'яне вкриття; праліс; квазіпраліс.

1 Лосюк Василь Петрович - член-кореспондент Лісівничої академії наук України, кандидат сільськогосподарських наук, науковий співробітник. Національний природний парк «Гуцульщина», вул. Дружби, 84, м. Косів, Івано-Франківська обл., 78600, Україна. Тел.: +034-78-23-709. E-mail: losyuk@i.ua ORCID: https://orcid.org/0000-0003-1807-1264

2 Погрібний Олег Олегович - кандидат сільськогосподарських наук, начальник наукового відділу. Національний природний парк «Гуцульщина», вул. Дружби, 84, м. Косів, Івано-Франківська обл., 78600, Україна. Тел.: +034-78-23-709. E-mail: pogribnyj@i.ua ORCID: https://orcid.org/0000-0002-8428-6514

3 Томич Марія Василівна - кандидат біологічних наук, начальник лабораторії екологічного моніторингу. Національний природний парк «Гуцульщина», вул. Дружби, 84, м. Косів, Івано-Франківська обл., 78600, Україна. Тел.: +034-78-23-709. E-mail: maritom82@ukr.net ORCID: https://orcid.org/0000-0002-7274-3618

4 Часковський Олег Григорович - кандидат сільськогосподарських наук, доцент кафедри лісової таксації та лісовпорядкування. Національний лісотехнічний університет України, вул. Генерала Чупринки, 103, м. Львів, 79057, Україна. Тел.:+032-237-80-94. E-mail: oleh. chaskov@googlemail.com ORCID https://orcid.org/0000-0003-0361-0624 Scopus ID: 26323447500

5 Ванджурак Павло Іванович - здобувач наукового ступеня кандидата сільськогосподарських наук. Національний лісотехнічний університет України, вул. Генерала Чупринки, 103, м. Львів 79057, Україна. Тел.: +0322-378094. E-mail: pavlov.76@ukr.net

6 Дебринюк Юрій Михайлович - академік Лісівничої академії наук України, академік-секретар ЛАН України, доктор сільськогосподарських наук, професор кафедри лісових культур і лісової селекції. Національний лісотехнічний університет України, вул. Генерала Чупринки, 103, м. Львів, 79057, Україна. Тел.: 032-235-30-12, +38-067-195-78-36. E-mail: debrynuk ju@ukr.net ORCID: http://orcid. org/0000-0002-0994-349X 
Вступ. Покутські Карпати розташовані у південно-східній частині північного мегасхилу Український Карпат і займають площу 659,7 км², що складає близько 3\% площі Українських Карпат (Гостюк, Мельник, 2017). Площа лісів Покутських Карпат становить 39,1 тис. га, 3 них, частка природних ялинових лісостанів $-8,2$ тис. га або $21 \%$ площі лісів регіону. Близько 30,3\% території Покутських Карпат віднесено до природно-заповідного фонду. Лісове господарство на цій території здійснюють п’ять лісокористувачів: ДП «Кутське ЛГ», ДП «Верховинське ЛГ», ДП «Гринявське ЛГ», Косівське районне підприємство «Райагроліс», Верховинський районний лісгосп та Національний природний парк «Гуцульщина».

Породний склад і структура лісів Покутських Карпат змінювалися відповідно до кліматичних умов геологічних періодів. Зокрема, Г.В. Козій (1950) виділяв шість стадій розвитку гірських східно-карпатських лісів. Так, у ранньому голоцені тут переважали мішані ліси 3 домінуванням Pinus sylvestris L. за участю Picea abies (L.) Karst.; в останньому льодовиковому періоді домінувала соснова стадія, лише 3 мінімальною часткою ялини або верби; у післяльодовиковий період березово-соснова стадія 3 вербою та сосною кедровою у високогір'ї; пізніше - стадія хвойношироколистяних ялиново-дубових лісів; ще пізніше - ялицево-букова стадія.

У першому тисячолітті використання лісів Гуцульщини людиною було здебільшого фрагментарним і не мало системного характеру. Інтенсивне освоєння цієї території припало на друге тисячоліття, яке почалося 3 примітивного випасання худоби та вирощування сільськогосподарських культур на полях поблизу населених пунктів і закінчилося масовим зрубуванням лісів у XIX-XX ст. внаслідок розвитку сільського господарства, промисловості та влаштування нових поселень. Впродовж агрокультурного періоду висотне розташування рослинності Карпат значно змінено, що найсильніше проявилося через трансформацію ялицево-букових лісів у ялинники та польові угіддя. Зміни мають висотний характер, будучи наймасштабнішими у поясі букових лісів (до висоти 800 м н.р.м.). Дещо слабші зміни відбулись у смузі мішаних лісів ялинового поясу (800-1100 м н.р.м.) і найслабші - в ялиновій смузі верхнього поясу (понад 1100 м н.р.м.) (Клапчук, 2006).

Історія досліджень лісів Покутських Карпат така ж давня, як і інших частин Українських Карпат і Прикарпаття. У XIX ст. флору Галичини описував В. Besser (1809). Територію регіону фрагментарно досліджували E. Wittman (1824a, 1824b), A. Zawadski (1835), F. Herbich (1865), A. Śleńdziński (1875, 1876), M. Raciborski (1886), L. Waigl (1883), I. Jachno (1884), O. Wołoszczak (1888). Рослинний покрив описав в етнографічній праці В. Шухевич (1899-1908). Фрагментарні дані подають також A. Wroblewski (1917), Н. Kozij (1936). Опис рослинного покриву наведено також у працях: Flora Polska
(1919-1980) за редакцією В. Шафера та у визначнику рослин Польщі (Szafer, Kulczyǹski, \& Pawłowski, 1924). P. Kontny (1937) виявив на досліджуваній території пеньки Taxus baccata L.

Рослинність Покутських Карпат у післявоєнний час вивчали співробітники кафедри ботаніки Чернівецького університету ім. Ю. Федьковича (Артемчук, Барикіна, 1965; Артемчук, Якимчук, 1973). Важливим етапом у вивченні лісових екосистем Українських Карпат став організований у 1964 р. Карпатський філіал при Українському науководослідному інституті лісівництва і агролісомеліорації імені Г.М. Висоцького (тепер - Український науково-дослідний інститут гірського лісівництва ім. П.С. Пастернака). Тут здійснювали наукові дослідження, спрямовані на вирішення основних проблем лісового господарства (Пастернак, 1961; Трибун, 1969; В. І. Парпан, Шпарик, Лосюк, 2003; B.I. Парпан, Шпарик, Т.В. Парпан, 2006 та ін.). Значний вклад у вивчення рослинності Українських Карпат внесли вчені Інституту екології Карпат (Голубець, 1967, 2003) та НЛТУ України (Герушинський, 1996; Чернявський, 2000) та ін.

Рельєф та історичний розвиток Покутських Карпат зумовив наявність пралісових ділянок, що входять до загальної мережі пралісів Свропи (Sabatini et al., 2018). Праліси є зразком природних стійких екосистем і вивчення їхньої структури $\epsilon$ завданням наближеного до природи лісівництва (Leibundgut, 1959).

На субформацію чисті букові ліси (Fageta) формації бука лісового (Fageta silvaticae) припадає 16,6 тис. га пралісів, на субформацію чисті ялинові ліси (Piceeta) формації ялини європейської (Piceetea excelsae) - 8,3 тис. га пралісів. Букових пралісів 3 домішкою Acer pseudoplatanus L. i Picea abies (L.) Karst, а також за участю Abies alba Mill. обліковано, відповідно, 4,8 та 4,5 тис. га. Мішані темнохвойнобукові праліси за участю Picea abies та Abies alba займають відповідно 2,7 і 1,0 тис. га (В.І. Парпан, Стойко, Т. В. Парпан, 2013).

Беручи до уваги характерні ценотичні ознаки пралісу, С.М. Стойко (2018) дає таке його визначення: праліс - це сформована упродовж філоценогенезу екосистема, в якій представлені усі вікові групи - від ювенільної до групи розпаду ценозу, взаємозв'язки між автотрофним і гетеротрофним блоками та педосферою, й тому він функціонує як саморегульована екосистема. Поряд з цим, квазіпраліси - це екосистеми, в окремих парцелах яких проявився незначний тимчасовий антропогенний вплив, який однак не змінив її природної ценотичної структури. У разі його припинення, впродовж певного періоду часу може відтворитися природний стан екосистеми.

Букові праліси Українських Карпат вивчено та описано вітчизняними і зарубіжними вченими досить повно (В.І. Парпан, Стойко, 1999; Чернявський, 2000; Brändli, Dowhanytsch, 2003; Стойко, 2018). Проте, ялинові праліси Українських Карпат ще недостатньо вивчені, а їхня структура може слу- 
гувати еталоном формування стійких смерекових насаджень Українських Карпат.

Об'єкти та методика досліджень. Об'єкт досліджень - природні ялинові ліси Покутських Карпат. Предмет дослідження - стан і структура природних ялинових лісів регіону, тенденції динаміки їхнього розвитку. Мета досліджень - оцінювання стану і структури природних ялинових угруповань Покутських Карпат.

Відповідно до проекту WWF-Україна «Ідентифікація пралісів Українських Карпат», обстежено ліси Покутських Карпат для визначення належності лісових територій до пралісових, квазіпралісових i природних ялинових угруповань. Основні таксаційні характеристики та динаміку сукцесій ялинових лісостанів проаналізовано на прикладі постійної пробної площі (ППП), закладеної в ялиновому природному лісі в умовах вологої чистої високогірної сусмеречини. Досліджуваний природний ліс відповідає практично всім ознакам ялинового пралісу, за винятком площі (<20 га). Тому досліджуваний об'єкт можна вважати природним лісом, який за своїми характеристиками максимально наближений до пралісу.

Польові дослідження здійснено 32010 p. 3 п'ятирічним інтервалом відповідно до методики екологічного моніторингу II рівня за програмою «ICPForest» із частковим доповненням положеннями загальноприйнятих методик 3 лісівничо-таксаційних досліджень (ГОСТ..., 1984; Вицега, Гриник, 2004; Герушинський, 1996; Король, Горошко, 2000; Горошко, Миклуш, Хомюк, 2004; Горошко та ін., 2012). Всю територію постійної пробної площі поділяли на квадрати розміром $10 \times 10$ м та присвоювали умовні координати $x$ i $y$ для подальшого визначення місцеположень розташованих на ППП дерев (Гриник, 2006; Вайс, 2007; Бойко, Тарнопільський, 2011).

Під час обстеження дерев здійснювали їх розподіл за шкалою Крафта на: домінуючі, що виді- ляються над наметом деревостану (I); панівні, що представляють головну частину деревостану (II); субпанівні, що входять до загального намету деревостану, але частково затінені (III); пригнічені, що досягають нижньої частини намету деревних крон (IV); цілком пригнічені, майже позбавлені гілок і відмирають (V); всохлі, мертві дерева $\left(\mathrm{V}^{\mathrm{a}}\right)$.

Таксаиійні та біометричні показники лісостанів визначали за методичними положеннями М.П. Горошка, С.І. Миклуша, П.Г. Хомюка (2004) та М.М. Грома (2005). Середні висоти дерев вираховували за формулою Чамана-Ріхарсона (Король, Горошко, 2000):

$$
H=a\left(1-e^{-b D_{1.3}}\right)^{c},
$$

де $H$ - висота дерева, м; $D$ - діаметр дерева, см; $a, b, c-$ коефіцієнти рівняння.

На підставі розрахованої висоти й діаметра для кожної ступені товщини у розрізі деревного виду розраховували видове число за формулою (Король, 2000):

$$
f=\frac{1}{1+e^{\left(\mathrm{b}_{1}+\frac{\mathrm{b}_{2}}{\ln (\mathrm{d})}+\frac{\mathrm{b}_{3}}{\ln (\mathrm{h})}+\mathrm{b}_{4} \cdot \mathrm{h} / \mathrm{d}\right)}},
$$

де $\mathrm{d}$ - діаметр дерева на висоті $1,3 \mathrm{~m}, \mathrm{~cm}$; $\mathrm{h}$ - висота дерева, $\mathrm{m} ; \mathrm{b}_{1} \ldots \mathrm{b}_{4}$ коефіцієнти рівняння.

Просторову структуру деревостанів вивчали на підставі вертикального й горизонтального розміщення дерев. Для дослідження горизонтальної структури, а також диференціації дерев у ступенях товщини використали бімодальний розподіл:

$$
f(x)=g \cdot f_{u}(x)+(1-g) \cdot f_{o}(x),
$$

де $f_{u}(x)$ - функція розподілу Вейбула для нижнього ярусу; $f_{o}(x)$ - функція розподілу Вейбула для верхнього ярусу; $g$ - параметр зв'язку двох функцій. Звідки,

$$
\left.f(x)=\left\{\begin{array}{l}
g \cdot\left[\frac{c_{u}}{b_{u}} \cdot\left(\frac{x-a_{u}}{b_{u}}\right)^{c_{u}-1} \cdot e^{-\left(\frac{x-a_{u}}{b_{u}}\right)^{c_{u}}}\right] \\
g \cdot\left[\frac{c_{u}}{b_{u}} \cdot\left(\frac{x-a_{u}}{b_{u}}\right)^{c_{u}-1} \cdot e^{-\left(\frac{x-a_{u}}{b_{u}}\right)^{c_{u}}}\right]+(1-g) \cdot\left[\frac{c_{o}}{b_{o}} \cdot\left(\frac{x-a_{o}}{b_{o}}\right)^{c_{o}-1} \cdot e^{-\left(\frac{x-a_{o}}{b_{o}}\right)^{c_{o}}}\right.
\end{array}\right\} \quad \begin{array}{r}
\text { якщо } x \leq a_{u} \\
\text { якщо } a_{o}<x \leq a_{u}
\end{array}\right\} \text { якщо } a_{o}<x
$$

де $x$ - значення варіанти, ступеня товщини; $a, b, c$ - коефіцієнти рівняння.

Tun просторового розмімення дерев на ППП визначали шляхом визначення індексу КлафамаКокса, за яким встановлювали тип розміщення особин. Для цього дослідну ділянку поділяли на квадрати $(10 \times 10$ м) і обліковували кількість дерев у кожному 3 них. Надалі встановлювали середню кількість дерев у квадраті, як частку від загальної кількості дерев на дослідній ділянці до кількості квадратів на цій ділянці. Значення індексу розраховували, як частку дисперсії до середньої кількості дерев (Король, 2000; Гриник, 2006; Вайс, 2007; Бойко, Тарнопільський, 2011; Горошко та ін., 2012): 


$$
1_{\mathrm{c}}=\frac{\delta^{2}}{n},
$$

де $1_{\text {c }}$ - індекс Кокса; $\delta^{2}-$ дисперсія; $n$ - середня кількість дерев в одному квадраті, шт.

На підставі значення індексу встановлювали тип розміщення: рівномірний (при $1_{c}<1,0$ ); груповий (при $\left.1_{c}>1,0\right)$ або випадковий (при $\left.1_{c}=1,0\right)$.

Видову структуру визначали за індексом Шеннона:

$$
\mathrm{H}^{\prime}\left(\mathrm{p}_{1}, p_{2}, \ldots . . p_{s}\right)=-\sum_{i=1}^{s} p_{i} \ln \left(p_{i}\right),
$$

де $H^{\prime}$ - індекс Шеннона; $s$ - кількість особин, шт.;

$$
\mathrm{p}_{\mathrm{i}}=n_{i} / N
$$

де $n_{i}$ - кількість особин одного виду, шт.; $N$ - загальна кількість особин, шт.

На підставі значення індексу визначали видову структуру: дуже низька (при $\mathrm{H}<0,06)$; низька (при 0,05 $<\mathrm{H}<0,16$ ); середня (при 0,15< $\mathrm{H}<0,31$ ); висока (при $0,30<\mathrm{H}<0,61$ ); дуже висока (при $\mathrm{H}>0,60)$.

Опис трав'яної рослинності здійснювали за методикою Браун-Бланке, а проективне вкриття лісових трав'яних видів (\%) визначали окомірно. Знаком «+» позначали проєктивне вкриття виду, якщо воно становило менше $1 \%$ або за наявності хоча б однієї особини трав'яного виду на ППП.

Приналежність лісостанів до пралісів, квазіпралісів і природних лісів Покутських Карпат встановлювали відповідно до положень «Методики визначення належності лісових територій до пралісів, квазіпралісів і природних лісів (2018).

Для достовірного встановлення загальної лісистості Покутських Карпат використано новітні GIS-методи дослідження, багатоканальні супутникові знімки Lansat та уточнену сучасну межу Покутських Карпат (Миклуш, Горошко, Часковський 2006; Гостюк, Мельник, 2017). За допомогою GISпрограм нами в межах території досліджень було розподілено пікселі растрового шару супутникового знімка на різні категорії земель, а саме: на хвойні ліси, листяні ліси, мішані ліси, луки, пасовища, ріллю, забудови, сади, води, кам'яні розсипища; в автоматичному режимі вирахувано кількість пікселів, розміром $30 \times 30$ м (рис. 1). Отже, перемноживши кількість пікселів на їхню площу встановлено загальну площу лісів регіону - 39,1 тис. га, з яких площа хвойних лісів становить 17,2 тис. га.

Результати та обговорення. Деякі дослідники виділяли в Українських Карпатах п’ять рослинних поясів: передгірський, нижній гірський лісовий, верхній гірський лісовий, субальпійський і альпійський (Комендар, 1957; Котов, Чопик, 1960). Проте М.А. Голубець $(1967,2003)$ вважав, що цей поділ на пояси не дає можливості розкрити геоботанічну сутність та еколого-географічну обумовленість висотного розподілу рослинності, і тому основою для виділення рослинних поясів повинна слугува- ти карта корінного рослинного покриву. Виходячи 3 цього положення, існує підстава стверджувати, що в Покутських Карпатах, починаючи 3 висоти понад 900 м н.р.м., серед хвойних і мішаних лісів корінними є виключно смерекові деревостани. Ліси 3 перевагою Abies alba формуються на нижчих висотах, а чисті соснові деревостани на території досліджуваного регіону відсутні. На створеній цифровій моделі рельєфу Покутських Карпат було побудовано ізолінію по висотних відмітках у 900 м н.р.м. та здійснено обчислення кількості пікселів за відповідними категоріями земель. За результатами підрахунків встановлено, що природні ялинові ліси на території Покутських Карпат займають площу 8,2 тис. га.

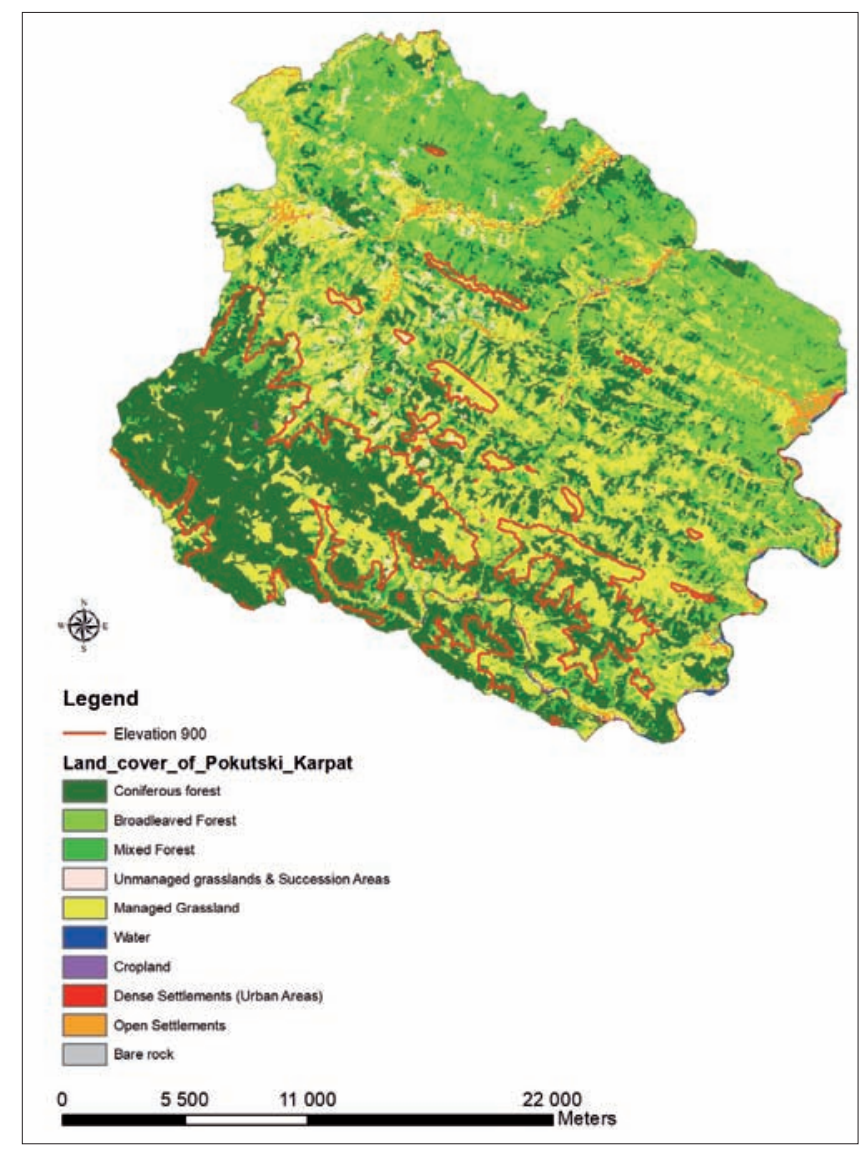

Рис. 1. Розподіл території Покутських Карпат за категоріями земель (за 3. В. Гостюк, А. В. Мельник, 2017)

Характеристику структури, стану, природного поновлення і трав'яного вкриття природних ялинових лісів Покутських Карпат розглянемо на прикладі ППП №5, закладеної у кв. 29, вид. 24 Космацького лісництва ДП «Кутське ЛГ». Пробна площа закладена у серпні 2010 р., а повторні обстеження здійснено у серпні 2015 та липні 2020 років. Характеристика ділянки така: категорія - заповідна зона НПП «Гуцульщина» без вилучення у користувачів (заповідне урочище «Грегіт»); висота над рівнем моря 1334-1360 м; грунти - бурі гірсько-лісові; тип лісорослинних умов - вологий сугруд $\left(C_{3}\right)$; тип лісу - чиста волога високогірна сусмеречина $\left(C_{3}-C M\right)$ (рис. 2$)$. 

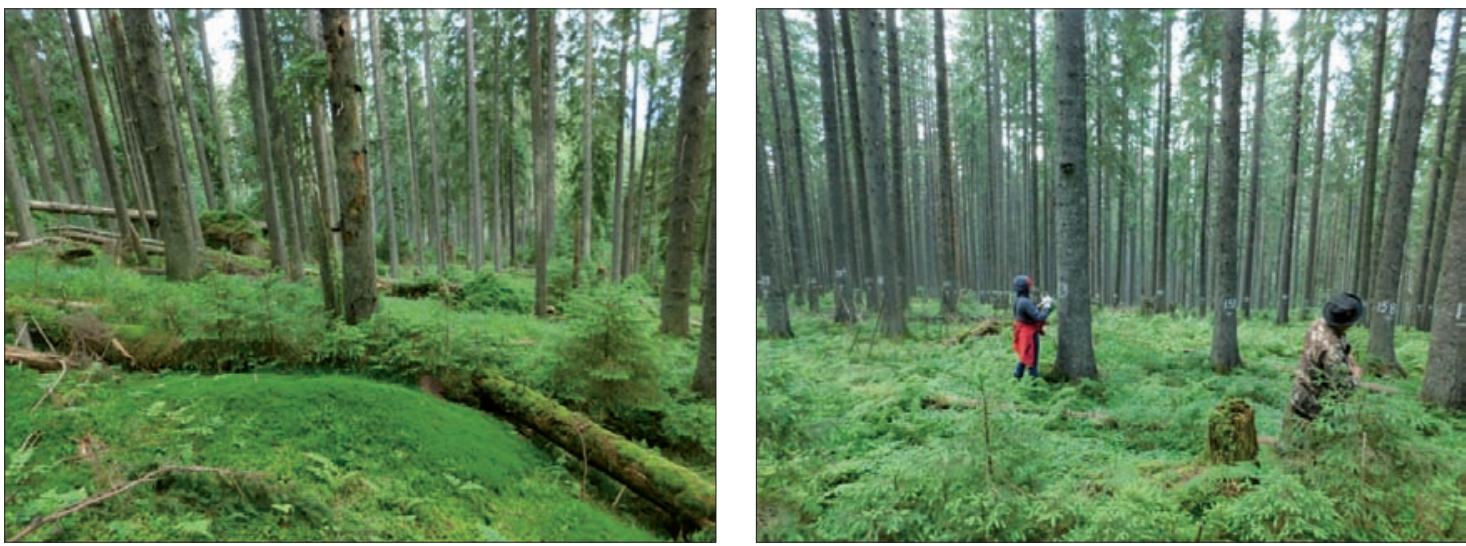

Рис. 2. Фрагменти загального вигляду ялинового лісостану в умовах чистої високогірної сусмеречини (ППП №5)

Постійна пробна площа має прямокутну форму $(62,5 \times 80$ м, 0,5 га), обмежена візирами і по периметру відзначена білою фарбою. Прив'язку ППП здійснено шляхом встановлення географічних координат за допомогою GPS-технологій. Під час дослідження визначали основні таксаційні показники всіх дерев у деревостані. Статистична характеристика розподілу дерев ялини європейської на ППП №5 за діаметром представлена в табл. 1. Наведені дані дають підставу стверджувати, що вибірка на ППП є репрезентативною, а їі статистичні показники - достовірними, оскільки дослід виконано 3 точністю 98,06\%.

Лісостан на ППП №5 представлений двоярусним, 3 частковим вираженням третього ярусу, корінним різновіковим чистим ялиновим деревостаном. Варто відзначити, що деревостан росте у від- носно багатих лісорослинних умовах, про що свідчать його достатньо високі загальні таксаційні показники (табл. 2).

Динаміка кількісних характеристик деревостану (табл. 3) за останні 10 років свідчить про деяке зменшення загальної кількості дерев. Впродовж 2015-2020 рр. відзначено різке збільшення особин ялини у другому ярусі, тоді як третьому ярусі кількість дерев стабільно низька. Кількість живих дерев першого ярусу впродовж 10-річного періоду спостережень суттєво знизилась (майже на 24\%).

Показники абсолютної та відносної повноти деревостану протягом 10-річного періоду дослідження є досить високими і подібними. Середній діаметр впродовж дослідження виявляє тенденцію до деякого зростання, тоді як показник середньої висоти змінюється слабо.

Статистика ряду розподілу дерев за діаметром на ППП №5

Таблиия 1

\begin{tabular}{|c|c|c|c|c|c|}
\hline $\begin{array}{c}\text { Середній } \\
\text { діаметр, } \mathrm{D}_{1.3}, \mathrm{~cm}\end{array}$ & $\begin{array}{c}\text { Середньо- } \\
\text { квадратичне } \\
\text { відхилення, см } \\
\end{array}$ & $\begin{array}{l}\text { Коефіцієнт } \\
\text { варіації, \% }\end{array}$ & Асиметрія & Ексцес & $\begin{array}{c}\text { Точність } \\
\text { досліду, \% }\end{array}$ \\
\hline $38,0 \pm 0,70$ & $11,94 \pm 0,49$ & $33,12 \pm 1,51$ & $-0,19 \pm 0,14$ & $-0,34 \pm 0,29$ & 1,94 \\
\hline
\end{tabular}

Таблиия 2

Таксаційні характеристика ялинового деревостану на ППП №5

\begin{tabular}{|c|c|c|c|c|c|c|}
\hline \multirow[b]{2}{*}{ Деревний вид } & \multirow{2}{*}{$\begin{array}{c}\text { Загальна кількість } \\
\text { дерев, шт. }\end{array}$} & \multirow{2}{*}{$\begin{array}{c}\text { Абсолютна } \\
\text { повнота, } \text { м²а га }^{-}\end{array}$} & \multicolumn{3}{|c|}{ Середні } & \multirow{2}{*}{$\begin{array}{c}\text { Запас } \\
\text { деревини, } \text { м }^{3}\end{array}$} \\
\hline & & & $\mathrm{D}, \mathrm{cm}$ & $\mathrm{H}, \mathrm{m}$ & А, роки & \\
\hline Ялина європейська & 292 & 33,08 & 38,0 & 27,1 & \multirow{2}{*}{$30-120$} & 460,9 \\
\hline Разом на 1 га & 584 & 66,16 & 38,0 & 27,1 & & 921,8 \\
\hline
\end{tabular}

Примітка. У загальну кількість дерев включено живі та сухостійні особини

Запас стовбурової деревини живих дерев має тенденцію до збільшення, особливо впродовж останнього 5-річного періоду. Поряд 3 цим, протягом цього ж проміжку часу спостережено різке зростання запасу деревини сухостійних особин, особливо - третього і другого ярусів.
Варто відзначити високу частку дерев без пошкоджень, хоча все ж існує тенденція до деякого зниження показника категорії їхнього стану.

Розподіл деревини живих і сухостійних дерев за запасом в межах ступенів товщини представлено на рис. 2. Найбільший запас деревини формують живі 
дерева 3 діаметром стовбурів 40-48 см. Це дерева першого ярусу - домінуючі і панівні, меншою мірою - субпанівні.

Найбільший запас сухостою формують дерева діаметром 28-36 см. Серед найкраще розвинутих дерев, які мають високий показник діаметра (48 см і більше), сухостій практично відсутній.

Варто відмітити, що досить значна амплітуда коливань дерев ялини європейської за діаметром дає підставу стверджувати про різновіковість деревостану. Додатковою підставою цьому твердженню $є$ наявність у лісостані трьох деревних ярусів, а також підросту різних вікових і висотних категорій.

Наведена діаграма на рис. 3 підтверджує, що найбільша частка дерев (72,5\%) росте в першому ярусі. Четверта частина дерев $(25,7 \%)$ формує другий ярус. Третій ярус є слабо вираженим, відносна кількість дерев в якому складає близько $2 \%$.

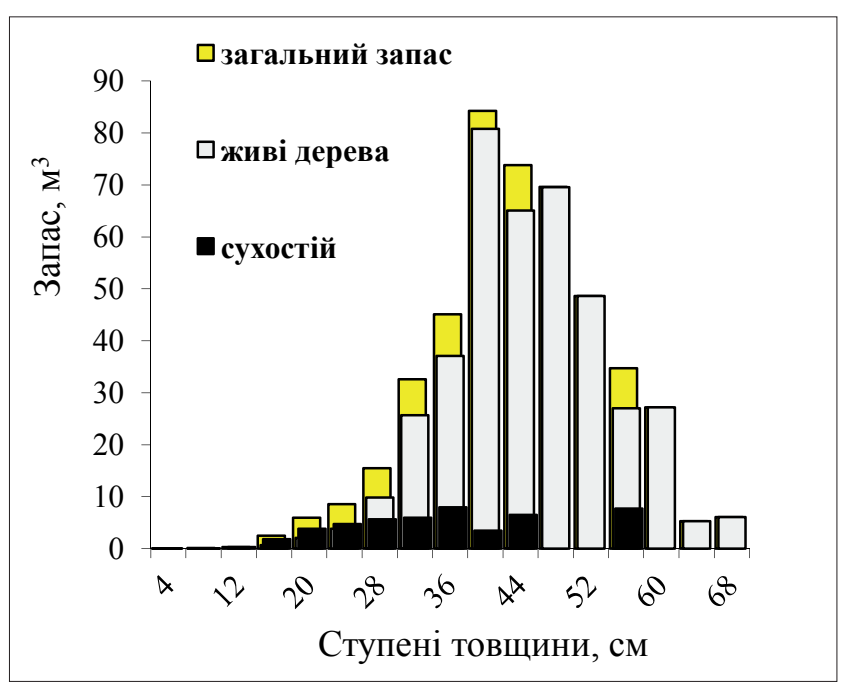

Рис. 2. Розподіл дерев за запасом стовбурової деревини на ППП №5 станом на 2020 рік

Таблиця 3

\section{Лісівничо-таксаційна характеристика ялинового деревостану на ППП №5}

\begin{tabular}{|c|c|c|c|c|c|c|c|c|c|c|c|c|}
\hline \multirow{2}{*}{ 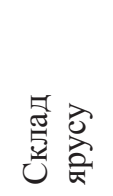 } & \multirow{2}{*}{ 릉 } & \multicolumn{2}{|c|}{$\begin{array}{c}\text { Кількість } \\
\text { живих дерев } \\
\text { на } 1 \text { га }\end{array}$} & \multirow{2}{*}{ 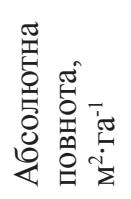 } & \multirow{2}{*}{ 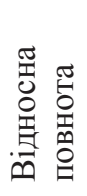 } & \multirow{2}{*}{ 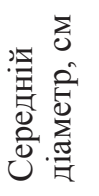 } & \multirow{2}{*}{ 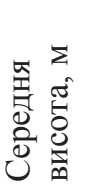 } & \multicolumn{2}{|c|}{$\begin{array}{c}\text { Запас стовбурової } \\
\text { деревини живих } \\
\text { дерев на } 1 \text { га }\end{array}$} & \multirow{2}{*}{ 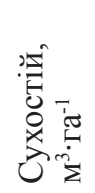 } & \multirow{2}{*}{ 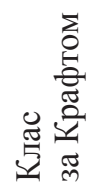 } & \multirow{2}{*}{ 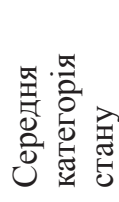 } \\
\hline & & шт. & $\%$ & & & & & $\mathrm{M}^{3}$ & $\%$ & & & \\
\hline \multicolumn{13}{|c|}{2010 рік } \\
\hline \multicolumn{13}{|c|}{ Ярус 1} \\
\hline $10 \mathrm{CM}$ & $\mathrm{CM}$ & 414 & 84 & 51,3 & 0,83 & 39,8 & 30,4 & 640,5 & 93,4 & 4,2 & 2,1 & 1,3 \\
\hline \multicolumn{13}{|c|}{ Ярус 2} \\
\hline $10 \mathrm{CM}$ & $\mathrm{CM}$ & 69 & 14 & 3,6 & 0,08 & 26,1 & 23,1 & 42,5 & 6,3 & 9,9 & 2,9 & 2,1 \\
\hline \multicolumn{13}{|c|}{ Ярус 3} \\
\hline $10 \mathrm{CM}$ & $\mathrm{CM}$ & 8 & 2 & 0,2 & 0,01 & 18,2 & 16,7 & 2,5 & 0,3 & 38,0 & 3,2 & 2,2 \\
\hline \multicolumn{13}{|c|}{ Весь деревостан } \\
\hline $10 \mathrm{CM}$ & $\mathrm{CM}$ & 491 & 100 & 55,1 & 0,92 & 37,5 & 29,6 & 685,5 & 100 & 52,1 & 3,0 & 1,4 \\
\hline \multicolumn{13}{|c|}{2015 рік } \\
\hline \multicolumn{13}{|c|}{ Ярус 1} \\
\hline $10 \mathrm{CM}$ & $\mathrm{CM}$ & 371 & 77 & 50,35 & 0,84 & 40,8 & 30,5 & 630,6 & 88,2 & 13,1 & 1,9 & 1,8 \\
\hline \multicolumn{13}{|c|}{ Ярус 2} \\
\hline $10 \mathrm{CM}$ & $\mathrm{CM}$ & 110 & 23 & 7,09 & 0,12 & 27,8 & 26,2 & 84,2 & 11,8 & 12,1 & 2,4 & 2,6 \\
\hline \multicolumn{13}{|c|}{ Ярус 3} \\
\hline $10 \mathrm{CM}$ & $\mathrm{CM}$ & 2 & 0 & 0,03 & 0,00 & 14,3 & 15,7 & 0,4 & 0,0 & 10,8 & 2,7 & 2,9 \\
\hline \multicolumn{13}{|c|}{ Весь деревостан } \\
\hline $10 \mathrm{CM}$ & $\mathrm{CM}$ & 483 & 100 & 57,48 & 0,96 & 37,7 & 29,7 & 715,2 & 100 & 36,0 & 2,1 & 2,0 \\
\hline \multicolumn{13}{|c|}{2020 рік } \\
\hline \multicolumn{13}{|c|}{ Ярус 1} \\
\hline $10 \mathrm{CM}$ & $\mathrm{CM}$ & 316 & 72,5 & 49,3 & 0,81 & 44,2 & 30,3 & 736,1 & 88,3 & 13,9 & 2,0 & 1,9 \\
\hline \multicolumn{13}{|c|}{ Ярус 2} \\
\hline $10 \mathrm{CM}$ & $\mathrm{CM}$ & 112 & 25,7 & 8,1 & 0,14 & 28,9 & 27 & 96,2 & 11,5 & 27,4 & 2,6 & 2,7 \\
\hline \multicolumn{13}{|c|}{ Ярус 3} \\
\hline $10 \mathrm{CM}$ & $\mathrm{Cm}$ & 8 & 1,8 & 0,2 & 0,01 & 26,1 & 17 & 1,4 & 0,2 & 46,8 & 2,7 & 3,0 \\
\hline \multicolumn{13}{|c|}{ Весь деревостан } \\
\hline $10 \mathrm{CM}$ & $\mathrm{CM}$ & 436 & 100 & 57,6 & 0,96 & 40,6 & 28,8 & 833,7 & 100 & 88,1 & 2,5 & 2,4 \\
\hline
\end{tabular}




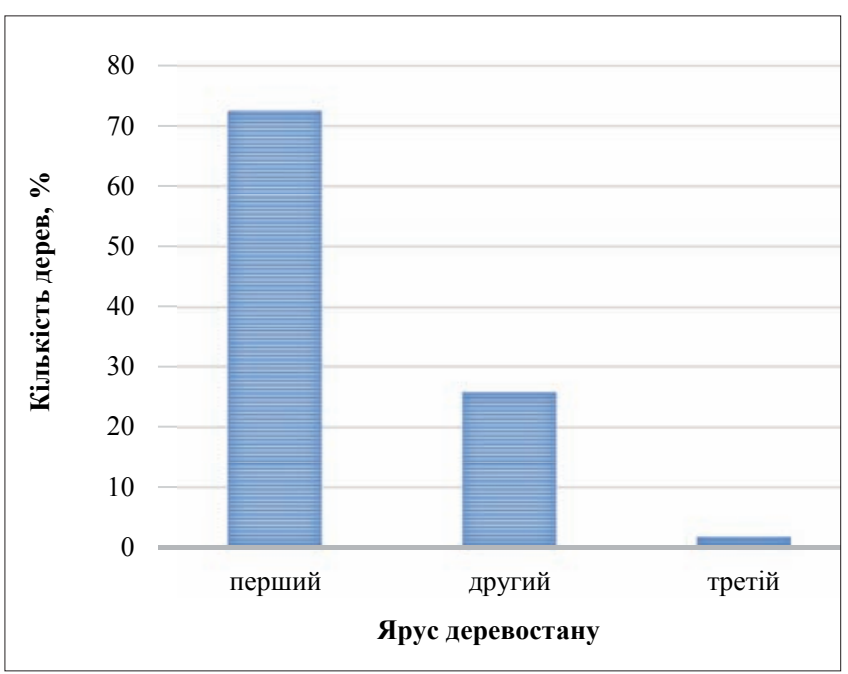

Рис. 3. Розподіл кількості дерев за ярусами у деревостані на ППП №5 станом на 2020 рік
Згідно 3 положеннями методики екологічного моніторингу II рівня за програмою «ICP-Forest», за таксаційною будовою деревостан є триярусним. Криві, що відображають динаміку висот дерев ялини кожного ярусу за ступенями товщини, наведено на рис. 4.

Фактичний розподіл дерев ялини європейської в досліджуваному деревостані наближається до модального розподілу, а, отже, цей аспект підтверджує природний процес розвитку деревостану (без втручання людини). Наявність грубих (і найстарших!) особин ялини у деревостані $\epsilon$ ще одним підтвердженням природного розвитку лісостану (рис. 5).

Окрім лісівничо-таксаційних показників досліджуваного деревостану, встановлено і біологічноекологічні особливості дерев на ППП. Нами здійснено розподіл дерев за класами Крафта, категоріями санітарного стану, пошкодженням крони $\mathrm{i}$ стовбура (табл. 4-6).

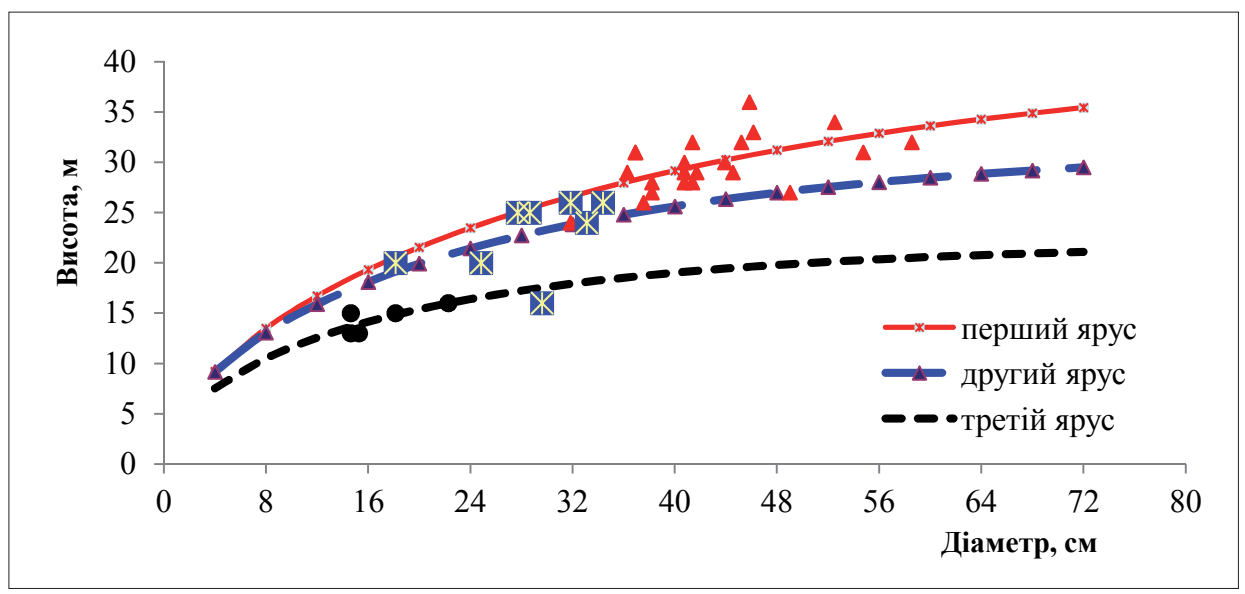

Рис. 4. Розподіл висоти дерев ялини європейської в межах ярусів деревостану на ППП №5 за результатами моніторингу 2020 року

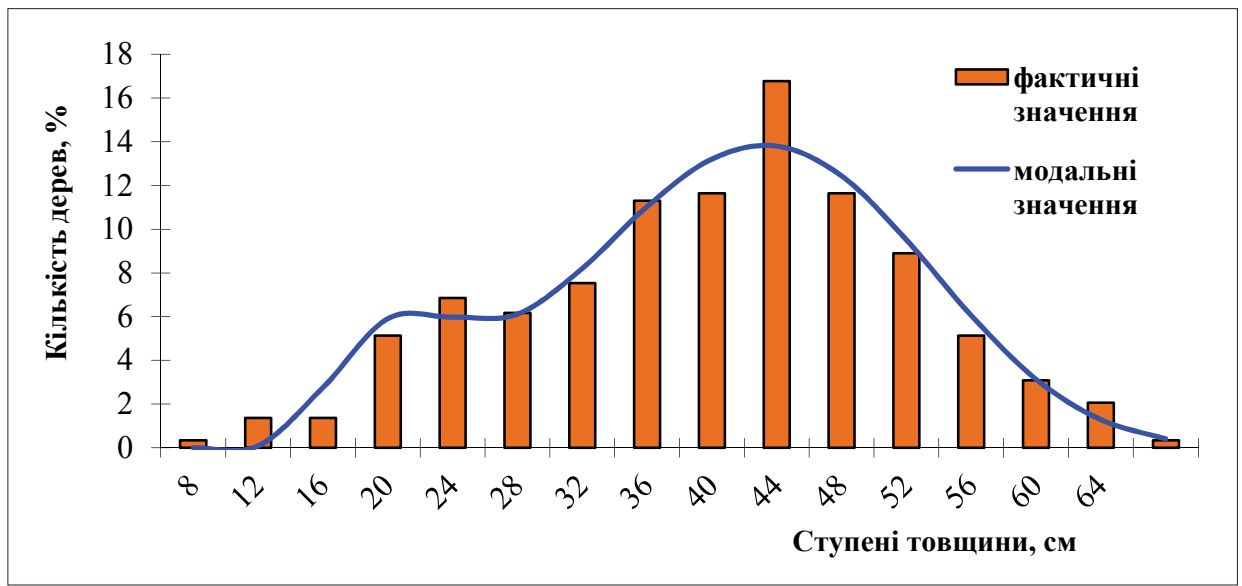

Рис. 5. Розподіл кількості живих дерев ялини за ступенями товщини в деревостані на ППП №5 станом на 2020 рік

Проаналізувавши розподіл дерев ялини за класами Крафта, можна стверджувати, що структура деревостану відповідає такому, який розвивається природним шляхом. Співвідношення дерев ялини різних класів є близьким до оптимального та відповідає принципу природному розвитку лісостану. Присут- ність дерев $\mathrm{V}^{\mathrm{a}}$ та $\mathrm{V}^{\sigma}$ класів також свідчить про природність проходження процесів розвитку деревостану та мінімальний вплив на них з боку людини.

Категорія санітарного стану є одним із найважливіших біологічних показників дерев у деревостані. У табл. 5 представлено розподіл дерев за відповідними 
категоріями стану. За наведеними результатами можна стверджувати, що санітарний стан дерев у досліджуваному деревостані є задовільним. Так, найбільшу частку представляють особини без ознак ослаблення; разом із ослабленими вони складають 73\% від загальної кількості дерев. Проте досить високою часткою у лісостані представлений і сухостій 25,4\%. Останній складений переважно пригніченими та цілком пригніченими в минулому деревами.

Таблиияя 4

\section{Розподіл дерев ялини європейської на ППП №5 за класами Крафта}

\begin{tabular}{cccccccc}
\hline & \multicolumn{7}{c}{ Клас Крафта } \\
\cline { 2 - 7 } & & & & & & & \\
\hline шт./га & 186 & 200 & 44 & 12 & 142 & 0 & 584 \\
\hline$\%$ & 31,8 & 34,2 & 7,5 & 2,1 & 24,3 & 0,0 & 100,0 \\
\hline
\end{tabular}

Використання нових методик, особливо тих, що активно застосовують у багатьох іноземних наукових установах, на сьогодні є важливим напрямом удосконалення наукових досліджень. Однією i3 них є методика IUFRO для визначення комплексної стійкості деревостану. Нами використано цю методику під час здійснення польових досліджень на ППП. Особливості розподілу дерев за класами IUFRO, згідно $з$ положеннями цієї методики, наведено у табл. 6.

За результатами останнього моніторингу (2020 р.), частка дерев без пошкоджень по деревостану загалом залишається відносно стабільною і становить в середньому 22-26\% впродовж періоду досліджень. Найменшу варіабельність за цим показником відзначено у дерев першого, найвищу - у дерев другого ярусів.

Клас життєвості дерев впродовж 10-річного періоду досліджень вказує на високу і середню життєвість особин $(1,4-1,8)$ ч зниження цього показника. За результатами досліджень 2020 р., найвища життєвість притаманна деревам першого ярусу, тоді як особини другого і третього ярусів відзначаються середнім показником життєвості.

\section{Розподіл дерев ялини на ППП №5 за категорісю санітарного стану}

Таблиия 5

\begin{tabular}{cccccccc}
\hline \multirow{2}{*}{$\begin{array}{c}\text { Одиниці } \\
\text { виміру }\end{array}$} & $\begin{array}{c}\text { Кез ознак } \\
\text { ослаблення }\end{array}$ & ослаблені & $\begin{array}{c}\text { сильно } \\
\text { ослаблені }\end{array}$ & всихаючі & $\begin{array}{c}\text { свіжий } \\
\text { сухостій }\end{array}$ & $\begin{array}{c}\text { сухостій } \\
\text { минулих років }\end{array}$ & Разом \\
\hline шт./г & 328 & 98 & 8 & 2 & 64 & 84 & 584 \\
\hline$\%$ & 56,2 & 16,8 & 1,4 & 0,3 & 11,0 & 14,4 & 100,0 \\
\hline
\end{tabular}

Таблиия 6

Розподіл дерев ялини свропейської за класами IUFRO та пошкодженнями у досліджуваному деревостані

\begin{tabular}{|c|c|c|c|c|c|c|c|c|c|c|c|c|c|c|c|c|c|}
\hline \multirow[b]{2}{*}{ 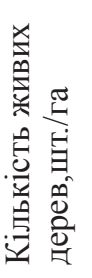 } & \multirow[b]{2}{*}{ 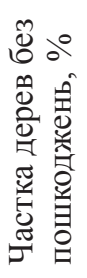 } & \multicolumn{6}{|c|}{ Класи IUFRO (середні) } & \multicolumn{10}{|c|}{ Кількість дерев за видами пошкоджень (шт./га) } \\
\hline & & $\underset{\overparen{2}}{\stackrel{\leftrightarrow}{2}}$ & 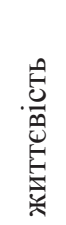 & 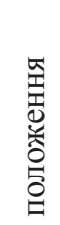 & 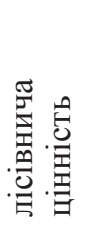 & 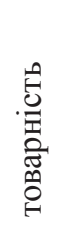 & 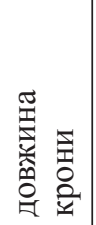 & 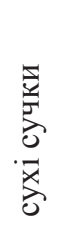 & 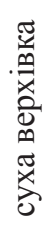 & 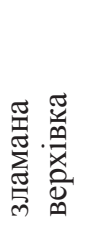 & 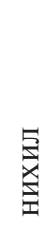 & 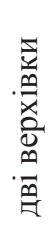 & 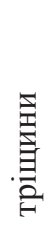 & $\underset{⿱ 乛}{E}$ & 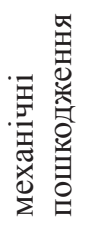 & 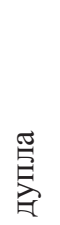 & 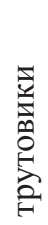 \\
\hline 1 & 2 & 3 & 4 & 5 & 6 & 7 & 8 & 9 & 10 & 11 & 12 & 13 & 14 & 15 & 16 & 17 & 18 \\
\hline \multicolumn{18}{|c|}{2010 рік } \\
\hline \multicolumn{18}{|c|}{ Ярус 1} \\
\hline 414 & 24,6 & 1 & 1,3 & 2,1 & 4,2 & 4,1 & 4,5 & 296 & 2 & 2 & 12 & 6 & 6 & 10 & 6 & 8 & - \\
\hline \multicolumn{18}{|c|}{ Яpyc 2} \\
\hline 69 & 36,2 & 2 & 1,7 & 1,4 & 4,7 & 4,2 & 4,8 & 31 & 2 & 2 & 6 & - & - & 2 & 2 & - & - \\
\hline \multicolumn{18}{|c|}{ Яpyc 3} \\
\hline 8 & 0,0 & 3 & 2 & 1,2 & 5 & 5 & 4,7 & 4 & - & - & 2 & - & - & - & 2 & - & - \\
\hline \multicolumn{18}{|c|}{ Весь деревостан } \\
\hline 491 & 25,8 & 1,2 & 1,4 & 2 & 4,3 & 4,1 & 4,6 & 331 & 4 & 4 & 20 & 6 & 6 & 12 & 10 & 8 & - \\
\hline \multicolumn{18}{|c|}{2015 рік } \\
\hline \multicolumn{18}{|c|}{ Яpyc 1} \\
\hline 356 & 26,4 & 1 & 1,5 & 2,2 & 4,1 & 4,0 & 4,7 & 238 & - & - & 4 & 2 & 17 & - & 6 & 6 & - \\
\hline
\end{tabular}


Продолж. табл. 6

\begin{tabular}{|c|c|c|c|c|c|c|c|c|c|c|c|c|c|c|c|c|c|}
\hline 1 & 2 & 3 & 4 & 5 & 6 & 7 & 8 & 9 & 10 & 11 & 12 & 13 & 14 & 15 & 16 & 17 & 18 \\
\hline \multicolumn{18}{|c|}{ Ярус 2} \\
\hline 106 & 9,4 & 2 & 2,0 & 1,5 & 4,5 & 4,3 & 5,1 & 60 & 2 & 23 & 2 & 2 & 6 & - & 2 & 2 & - \\
\hline \multicolumn{18}{|c|}{ Ярус 3} \\
\hline 2 & 0,0 & 3 & 2,0 & 2,0 & 5,0 & 5,0 & 5,0 & 2 & - & - & - & - & - & - & - & - & - \\
\hline \multicolumn{18}{|c|}{ Весь деревостан } \\
\hline 464 & 22,4 & 1,2 & 1,6 & 2,1 & 4,2 & 4,1 & 4,8 & 300 & 2 & 23 & 6 & 4 & 23 & - & 8 & 8 & - \\
\hline \multicolumn{18}{|c|}{2020 рік } \\
\hline \multicolumn{18}{|c|}{ Ярус 1} \\
\hline 316 & 20,9 & 1 & 1,6 & 1,6 & 4 & 4 & 4,9 & 229 & 1 & 1 & 5 & 4 & 12 & 5 & 3 & 1 & 4 \\
\hline \multicolumn{18}{|c|}{ Ярус 2} \\
\hline 112 & 29,3 & 2 & 2 & 2 & 4,85 & 4,7 & 5,1 & 88 & 4 & 6 & 4 & 3 & 7 & 4 & 2 & - & 1 \\
\hline \multicolumn{18}{|c|}{ Ярус 3} \\
\hline 8 & 50,0 & 3 & 2 & 2 & 5,2 & 5,1 & 5,5 & 8 & - & 18 & 1 & - & - & 1 & - & - & - \\
\hline \multicolumn{18}{|c|}{ Весь деревостан } \\
\hline 436 & 26,1 & 1,6 & 1,8 & 1,8 & 4,8 & 4,6 & 5,1 & 325 & 5 & 25 & 10 & 7 & 19 & 10 & 5 & 1 & 5 \\
\hline
\end{tabular}

Показник класу положення дерева у деревостані підтверджує, що більшість дерев не мають ознак пригнічення, тобто володіють необхідним простором для росту. Його середнє значення для деревостану складає 1,81 , а для ярусів - 1,6-2,0. Що стосується динаміки цього показника, то за останніх п'ять років він дещо зменшився за рахунок збільшення дерев у другому і третьому ярусах.

Клас лісівничої цінності дерев в межах ярусів помітно знижується - від 4,0 (перший ярус) до 5,2 (третій ярус), що цілком закономірно з огляду на ярусне розташування особин. Впродовж 10-річного циклу досліджень також спостережено деяке зниження показника (від 4,3 до 4,8), що є результатом динамічного зменшення дерев першого ярусу впродовж 10-річного періоду.

Показники класу товарності дерев за ярусами змінюються від 4,0 у першому до 5,1-у третьому ярусах. Можна відзначити високу товарність дерев першого ярусу, де переважають ділові стовбури ялини. Загалом показник має незначну тенденцію до зменшення, насамперед, внаслідок зниження кількості дерев ялини у першому ярусі, де переважають ділові екземпляри.

Середнє значення класу довжини крони становить 5,1, а в межах ярусів показник змінюється від 4,9 до 5,5. На основі отриманих значень можна стверджувати, що більшість дерев мають крону, довжина якої становить більш ніж половину висоти стовбура. Такі дерева складають основну (стабілізуючу) частину деревостану. Поряд 3 цим, упродовж 10-річного періоду спостережено деяке зменшення показника класу довжини крони, що може свідчити про зниження біотичної стійкості насадження загалом.
Основними видами пошкоджень, які виявлено у деревостані на ППП №5, є наявність значної кількості дерев з різною часткою (від 10 до 70\%) сухих сучків (325 шт./га). Досить часто трапляються дерева зі зламаною (25 шт./га) та сухою верхівкою (5 шт./га), 3 двома верхівками (7 шт./га), а також дерева 3 тріщинами (19 шт./га). Кількість нахилених дерев і дерев 3 вигнутим стовбуром становить, відповідно, по 10 шт. на 1 га. На поодиноких деревах виявлено трутовики, дупла та механічні пошкодження (1-5 шт./га).

Динаміка пошкоджень впродовж останнього десятиріччя доволі стабільна. Трутовики виявлено лише під час останнього обстеження (2020р.), що підтверджує поступове зниження біотичної стійкості деревостану загалом.

Окрім лісівничо-таксаційних показників деревостану, нами також досліджено просторову та видову його структури. Просторову горизонтальну структуру досліджували шляхом присвоєння кожному обліковому дереву на ППП умовних координат за допомогою координатної сітки. Просторове розташування дерев на ППП №5 зображено на рис. 6 .

Згідно встановленого індекса Кокса $(1,2)$, для досліджуваного деревостану характерний груповий тип розташування дерев, який визначається, насамперед, розташуванням дерев першого ярусу. Такий тип розміщення притаманний деревостанам природного походження, які і надалі продовжують розвиватися природним шляхом без антропогенного втручання. Зімкнутість крон в куртинах змінюється від 0,8 до 1 , а середня повнота на ППП становить 0,96 .

Розрахований для лісостану індекс різноманітності Шеннона виявився дуже низьким $(\mathrm{H}<0,06)$, 
оскільки об’єктом дослідження є чистий ялиновий деревостан.

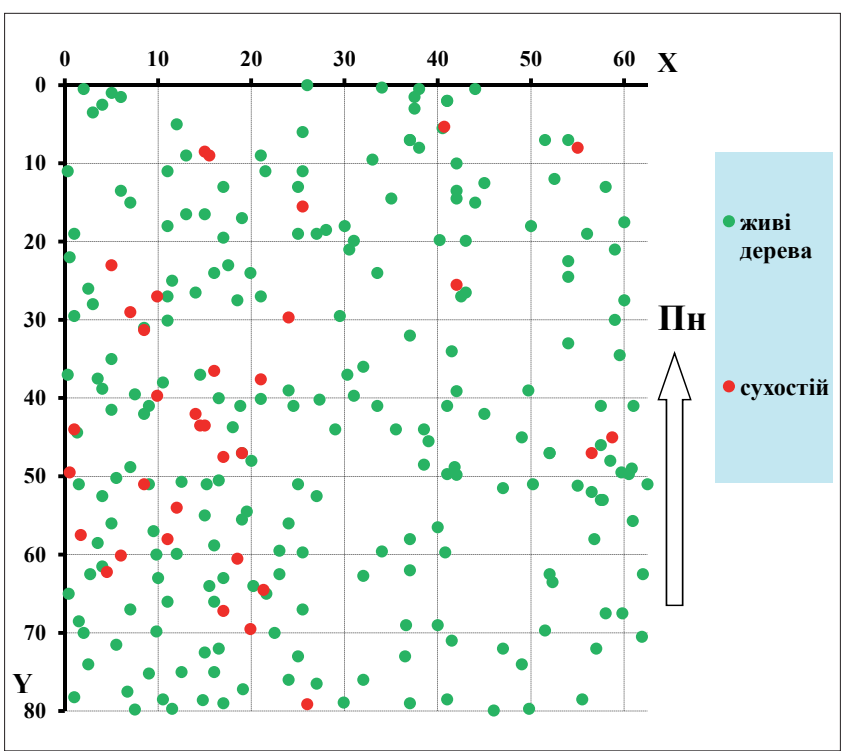

Рис. 6. Горизонтальне розташування дерев ялини європейської на ППП №5

Розподіл мертвої лежачої деревини за ступенем розкладання наведено у табл. 7. На досліджуваній пробній площі знаходиться 230 мертвих лежачих дерев або їхніх частин із запасом 86,4 м³ га. Найбільший запас характерний для тих особин, деревина яких знаходяться у фазі сильного розкладання $-48,6 \mathrm{~m}^{3} /$ га.

Впродовж останнього п'ятиріччя відзначено збільшення запасу мертвої деревини, особливо на 1-й та 4-й стадіях розкладання. Поряд 3 цим, запас мертвої лежачої деревини, порівняно з 2010 р. $\left(128,8 \mathrm{~m}^{3} /\right.$ га), дещо зменшився, особливо на сильній і слабкій стадіях розкладання.

Дослідження процесу проходження природного поновлення деревних порід на ППП здійснено за методикою обліку підросту IUFRO, котра передбачає закладання п'яти кругових облікових площадок площею $20 \mathrm{~m}^{2}$ кожна. На облікових площадках до розрахунку включали всю кількість підросту із його поділом на висотні групи.

Загальний розподіл підросту із його перерахунком на 1 га представлено в табл. 8. Варто відзначити високу чисельність підросту ялини найнижчих висотних груп. Цей молодий підріст з'являється у «вікнах» лісового намету на місці вітровальних і буреломних дерев. Проте він не довговічний i, внаслідок дії несприятливих природних чинників (засухи, задерніння грунту тощо), гине впродовж наступних декількох років, що підтверджено низькою кількістю ялинового підросту у вищих висотних групах.

Таблиця 7

Розподіл запасу мертвої лежачої деревини у природному лісостані за ступенем розкладання

\begin{tabular}{|c|c|c|c|c|c|c|}
\hline \multirow{2}{*}{ Порода } & \multirow{2}{*}{ Запас, м³/га } & \multirow{2}{*}{$\begin{array}{c}\text { К-сть } \\
\text { колод, шт./га }\end{array}$} & \multicolumn{4}{|c|}{ Запас за ступенем розкладання, м³/га } \\
\hline & & & 1 & 2 & 3 & 4 \\
\hline \multicolumn{7}{|c|}{2010 рік } \\
\hline Ялина & 128,7 & 289 & 7,9 & 13,7 & 53,9 & 53,2 \\
\hline \multicolumn{7}{|c|}{2015 рік } \\
\hline Ялина & 62,2 & 100 & 3,4 & 10,8 & 18,6 & 29,4 \\
\hline \multicolumn{7}{|c|}{2020 рік } \\
\hline Ялина & 86,4 & 230 & 13,9 & 10,9 & 13,0 & 48,6 \\
\hline
\end{tabular}

Результати обліку підросту деревних порід на ППП №5

Таблиия 8

\begin{tabular}{|c|c|c|c|c|c|c|c|c|}
\hline \multirow{2}{*}{ Порода } & \multicolumn{7}{|c|}{ В тому числі за висотними групами, шт./га } & \multirow{2}{*}{$\begin{array}{c}\text { Всього, } \\
\text { шт./га }\end{array}$} \\
\hline & $10-20 \mathrm{~cm}$ & $21-30 \mathrm{~cm}$ & $31-50 \mathrm{~cm}$ & $51-70 \mathrm{~cm}$ & $71-90 \mathrm{~cm}$ & $91-130 \mathrm{~cm}$ & $>130 \mathrm{~cm}$ & \\
\hline \multicolumn{9}{|c|}{2010 рік } \\
\hline Ялина & 5750 & 2750 & 1250 & 125 & 62 & 125 & - & 10062 \\
\hline Горобина & - & - & - & 62 & 125 & 62 & - & 249 \\
\hline Разом & 5750 & 2750 & 1250 & 187 & 187 & 187 & - & 10311 \\
\hline \multicolumn{9}{|c|}{2015 рік } \\
\hline Ялина & 7812 & 3906 & 2995 & 1302 & 651 & 781 & 260 & 17707 \\
\hline Горобина & - & - & - & 391 & - & 130 & 260 & 781 \\
\hline Разом & 7812 & 3906 & 2995 & 1693 & 651 & 911 & 520 & 18488 \\
\hline \multicolumn{9}{|c|}{2020 рік } \\
\hline Ялина & 13900 & 1600 & 1600 & 100 & 100 & 100 & 100 & 17500 \\
\hline Разом & 13900 & 1600 & 1600 & 100 & 100 & 100 & 100 & 17500 \\
\hline
\end{tabular}


Динаміка кількості природного поновлення впродовж останніх п'яти років суттєво не змінилась, однак суттєво збільшилась порівняно з 2010 роком. Збільшення кількості підросту відбувається за рахунок ялини, особливо у першій висотній групі. Натомість кількість підросту в інших висотних групах суттєво зменшилася. Отримані результати підтверджують, що частина природного поновлення гине 3 переходом у більшу висотну групу і цей аспект зумовлює проблему під час формування корінного деревостану.

Підлісок на пробній площі відсутній. Проте присутні трав'яні види, які формують тут досить щільний покрив, проєктивне вкриття якого становить 80-85\%. Активна вегетація на досліджуваній ППП починається лише наприкінці травня, що є характерною особливістю для середньогірної частини Парку.

У травні 2020 р. на ППП-5 ідентифіковано минулорічні пагони п'яти видів трав'яних рослин 3 проективним вкриттям 70\%. У липні обліковано 34 види із загальним проективним вкриттям $85 \%$. Видовий склад трав'яних рослин 3 їх проективним вкриттям (\%) на ділянці такий: Luzula sylvatica (Hudson) Gaudin - 30, Athyrium filix-femina (L.) Roth. - 25, Vaccinium myrtillus L. - 15, Oxalis acetosella L. -15 , Dryopteris dilatata Hoffm. A. Gray - 12, Homogyne alpine (L.) Cass. - 15, Huperzia selago (L.) Bernh. ex Schrank et C. Mart. - 5, Rumex pseudoalpinus Hoefft - 5, Soldanella hungarica Simonk. - 5, Campanula patula L. - 3, Circaea alpina L. - 3, Anthriscus sylvestris (L.) Hoffm. - 3, Agrostis capillaris L. (A. tenuis Sibth.) - 3, Adenostyles alliariae (Gouan) Kern. - 2, Anagallis arvensis L. - 2, Anemone nemorosa L. - 2, Myosotis sylvatica Ehrh. ex Hoffm. 1, Dentaria glandulosa Waldst. et Kit. - +, Impatiens noli-tangere L. - +, Symphytum cordatum Waldst. et Kit. ex Willd. - +, Calamagrostis arundinacea (L.) Roth - +, Circaea lutetiana L. - +, Galeobdolon luteum Huds. - +, Gymnocarpium dryopteris (L.) Newman + , Hieracium sylvularum Jord. ex Boreau,-+ Luzula luzuloides (Lam.) Dandy et Wilmott - +, Petasites albus (L.) P. Gaertn. - +, Phegopteris connectilis (Michx.) Watt. - +, Rubus hirtus Waldst. et Kit. - +, Rubus idaeus L. - +, Streptopus amplexifolius (L.) DC. - +, Symphytum cordatum Waldst. et Kit. ex Willd. - +.

Отже, у середині липня на ППП у трав'яному ярусі домінували шість видів - Vaccinium myrtillus, Oxalis acetosella, Luzula sylvatica, Dryopteris dilatata, Homogyne alpine та Athyrium filix-femina. За результатами десятирічних досліджень спостережено появу на ділянці видів, більш характерних для фагетальних комплексів - Anemone nemorosa, Dentaria glandulosa, Impatiens noli-tangere, Symphytum cordatum. 3 іншого боку, впродовж 10-річного періоду з ППП зникли трав'яні види, які траплялися поодиноко і були світлолюбнішими, ніж інші типові сильванти - Cirsium walldsteinii Rouy, Gentiana asclepiadea L., Leucanthemum rotundifolium (Waldst. et Kit. ex Willd.) DC. Необхідно зазначити, що на ППП у 2020 р. не виявлено Lycopodium annotinum L., що може бути пов'язано як з глобальними кліматичними змінами, так і локальними процесами у межах досліджуваної ділянки.

Проєктивне вкриття мохів за моніторинговий період суттєво не змінилося і становить більше 90\%, серед яких домінують Polytrichum соттиnae- $60 \%$, Dicranum rugosum - 30\% та Hylocomium splendens $-3 \%$.

Еталонами розвитку природних лісів $є$ праліси та квазі-праліси. Саме в цих лісових угрупованнях можна відстежити природні процеси розвитку ялинових лісостанів, що відбуваються без антропогенного впливу.

За результатами інвентаризації лісових масивів Українських Карпат (відповідно до проекту WWFУкраїна «Ідентифікація пралісів Українських Карпат») нами створено інтерактивну карту поширення пралісів і квазіпралісів досліджуваної теритоpiï. За допомогою GIS-програм на карту накладено межі Покутських Карпат та отримано схему розташування пралісових угруповань на цій теритоpiї (рис. 7). Варто зазначити, що на карту нанесено об'єкти, які вже отримали офіційний статус пралісових та квазіпралісових ділянок, а також ті, які проінвентеризовано, однак статус яких ще не погоджено $з$ постійними землекористувачами. Загалом на територій Покутських Карпат офіційний статус отримали 65,3 га ялинових пралісів, проте ще 267 га ялинових пралісів і квазіпралісів не отримали погодження на присвоєння цього статусу від постійних землекористувачів.

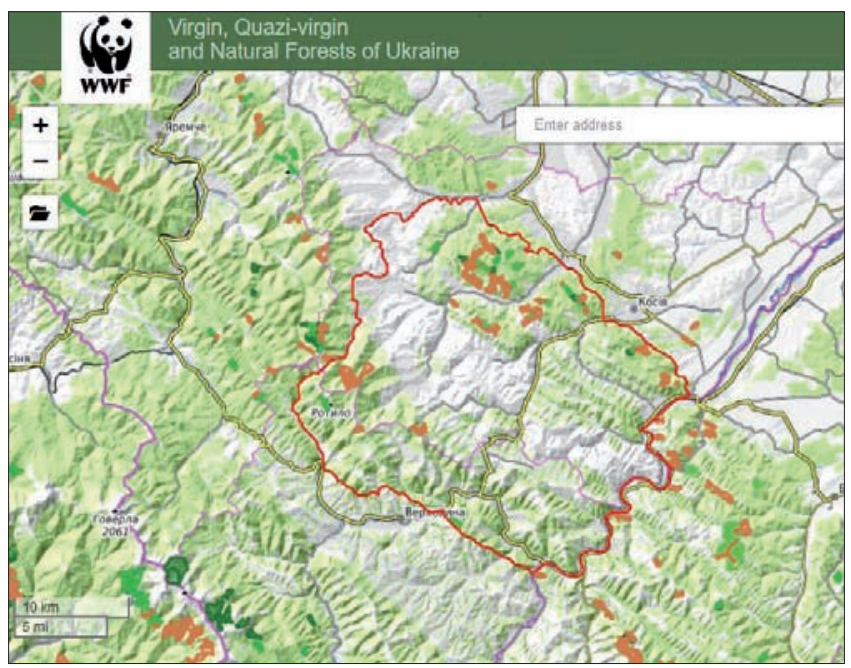

Рис. 7. Схема розташування пралісів і квазіпралісів Покутських Карпат (http://gis-wwf.com.ua/)

Висновки. Природні ялинові ліси займають найвищі хребти та вершини середньогір'я Покутських Карпат на висотах 900-1400 м н.р.м. і виконують, насамперед, протиерозійні, водорегулятивні, грунтозахисні та інші важливі функції.

Природні ялинові ліси Покутських Карпат характеризуються такими показниками: високою кількістю дерев та високим запасом стовбурової деревини; значним запасом мертвої лежачої деревини; близькою до середньої життєвістю дерев і високою 
x товарністю; достатньою кількістю підросту нижчих висотних груп та недостатньою - вищих; незначним антропогенним впливом. Лісові трав'яні види формують досить щільний покрив, проєктивне вкриття якого становить $85 \%$ за наявності більше 30 видів. Поряд 3 цим, спостережено процеси трансформації рослинного покриву у природних ялинових лісах.

Вивчення стану і структури ялинових пралісових та квазіпралісових кластерів на території Покутських Карпат у динаміці дасть можливість спрогнозувати подальший розвиток природних ялинових лісів на досліджуваній території.

Останні моніторингові дослідження виявили деяке зниження показників категорії стану, життєвості, товарності, довжини крони у дерев ялини європейської, збільшення обсягу сухостою та видів пошкоджень, порівняно із 2010 роком. Причина полягає, насамперед, у кліматичних змінах, на які ялинові ліси реагують особливо відчутно.

\section{Список літератури}

Артемчук I. В., Барикіна Т.В. (1965). Геоботанічна характеристика природних кормових угідь Покутських Карпат. Флора $і$ фауна Украӥнських Kapnam: матеріали доповідей міжвуз. ювілейн. конф., присвяч. 20-річчю Ужгородського держ. ун-ту, 12-13. Ужгород, Україна: Ужгородський держ. ун-т [Artemchuk, I. V., \& Barikina, T. V. (1956). Geobotanical characteristic of natural feeds of the Pokutsky Carpathians. In Flora and fauna of Ukrainian Carpathians, 12-13. Uzhgorod, Ukraine: Uzhgorod State University] (in Ukrainian)

Артемчук I.В., Якимчук М.К. (1973). Луки Покутського Прикарпаття й шляхи їх поліпшення. Український ботанічний журнал, 31(5), 605-609. [Artemchuk, I. V., \& Yakymchuk, M. K. (1973). Meadows of Pokutsky Prykarpattia and ways to improve them. Ukrainian Botanical Journal, 31(5), 605-609] (in Ukrainian)

Бойко С. В., Тарнопільський О. М. (2011). Типи розміщення дерев у природних сосняках. Науковий вісник НЛТУ Украӥни, 21(5), 71-74. [Boiko, S. V., \& Tarnopilskyi, O. M. (2011). Types of tree placement in natural pines. Scientific Bulletin of Ukrainian National Forestry University, 21(5), 71-74. Retrieved from https://nv.nltu. edu.ua/Archive/2011/21_5/index.htm] (in Ukrainian)

Вайс А. А. (2007). Классификация деревьев и горизонтальная структура ценозов Научный журнал КубГАУ, 31(7), 1-13. [Vais, A.A. (2007). Types of tree placement in natural pines Scientific Journal of the Kuban State Agrarian University, 31(7), 1-13. Retrieved from http://ej.kubagro.ru/2007/07/pdf/14.pdf] (in Russian)

Вицега Р.Р., Гриник Г.Г. (2004). Таксаційна будова смерекових деревостанів за діаметром. Науковий вісник НЛТУ України, 14(4), 55-58. [Vytseha R. R., \& Hrynyk, H.H. (2004). Taxation structure of spruce stands according to diameter. Scientific Bulletin of Ukrainian National Forestry University, 14(4), 55-58. Retrieved from
https://nv.nltu.edu.ua/Archive/2004/14_4/index14_4.htm] (in Ukrainian)

Герушинський 3. Ю. (1996). Типологія лісів Украӥнських Kapnam. Львів: Піраміда. 208 с. [Herushynskyi, Z.Iu. (1996) Typology of Forests of the Ukrainian Carpathians. Lviv: Pyramida. ISBN 5-7763-9366-3] (in Ukrainian)

Голубець М.А. (2003). Геоботанічне районування Українських Карпат - основа раціонального природокористування. Екологічний збірник: Екологічні проблеми Карпатського регіону. Наукове товариство ім. Т. Шевченка, XII, 283-292. [Holubets, M.A. (2003) Geobotanical zoning of the Ukrainian Carpathians - the basis of rational using of nature. Ecological collection: Ecological problems of the Carpathian region. Scientific Society by T. Shevchenko, XII, 283-292] (in Ukrainian)

Голубец М. А. (1967). О высотной зональности растительного покрова Украинских Карпат. Проблемы ботаники: Растительный мир высокогорий СССР и вопросы его использования, 9, 56-60. [Holubets, M.A. (1967). About the high-altitude zonality of the vegetation cover of the Ukrainian Carpathians. Problems of botany: The flor a of the highlands of the USSR and questions of its use, 9, 56-60] (in Russian)

Горошко М.П., Миклуш С.І., Хомюк П. Г. (2004). Біометрія. Львів: Камула. 236 с. [Horoshko, М.Р., Myklush, S.I., \& Khomiuk, P.H. Biometrics. Lviv: Kamula. ISBN 5-7763-1486-0] (in Ukrainian)

Горошко М.П., Миклуш С. І., Король М.М., Білас М.Ю., Миклуш Ю.С. (2012). Теоретичні аспекти оцінки просторової структури насаджень. Наукові основи підвищення продуктивності та біологічної стійкості лісових та урбанізованих екосистем: матеріали 62-ої наук.-техн. конф. професорського-викладацького складу, наукових працівників, докторантів та аспірантів за підсумками наукової діяльності у 2011 р., 31-34. Львів, Україна: Національний лісотехнічний ун-т України. [Horoshko, M.P., Myklush, S.I., Korol, M. M., Bilas, M.Iu., Myklush, Yu. S. (2012). Theoretical aspects of assessment of spatial structure of plantations. In Scientific principles of improvement of productivity and biological stability of forest and urban ecosystems, 31-34. Lviv, Ukraine: Ukrainian National Forestry University] (in Ukrainian)

ГОСТ 56-69-83. Плошади пробне лесоустроительные. Метод закладки. [Введен в действие 1984-01-01]. Издание офиц. Москва: ЦБНТИ Гослесхоза CCCP [GOST 56-69-83. The trial areas of forest management areas. Bookmark method. [Effective from January 01, 1984]. Official edition. Moscow: CBNTI Gosleskhoz of the USSR] (in Russian)

Гостюк 3.В., Мельник А.В. (2017). Покутські Карпати в системі фізико-географічного районування Українських Карпат. Фізична географія mа геоморфологія, 4(88), 12-21. [Hostiuk, Z.V., \& Melnyk, A. V. (2017). Pokutski Carpathians in the system of physical and geographical zoning of the Ukrainian Carpathians. Physical geography and geomorphology, 
4(88), 12-21. Retrieved from http://nbuv.gov.ua/UJRN/ fiz geo $2017 \quad 4 \quad 4$ ] (in Ukrainian)

Гриник Г.Г. (2006). Дослідження впливу горизонтальної структури ялинових деревостанів на будову за відносними показниками морфологічних показників деревостанів ДП «Сколівське лісове господарство». Науковий вісник НЛТУ України, 16(6), 52-56. [Hrynyk, H. H. (2006). Researching of influence of horizontal structure of the spruce stands on structure according to relative indicators of morphological indicators of stands of DP «Skole forestry». Scientific Bulletin of Ukrainian National Forestry University, 16(6), 52-56. Retrieved from https://nv.nltu.edu.ua/Archive/2006/16_6/ index.htm] (in Ukrainian)

Гром М.М. (2005). Лісова таксація. Львів: УкрДЛТУ. 416 с. [Hrom, М. М. (2005). Forest Taxation. Lviv: Ukrainian State Forestry University. ISBN 5-77630179-3] (in Ukrainian)

Клапчук В.M. (2006) Схема визначення пріоритетів антропогенного впливу на природні екосистеми. Наукові основи ведення сталого лісового господарства: матеріали міжнародної наук.практ. конф., 92-94. Івано-Франківськ, Україна: Український науково-дослідний інститут гірського лісівництва. [Klapchuk, V.M. (2006). Scheme for determination of the priorities of anthropogenic impact on the natural ecosystems. In Scientific bases of sustainable forestry management: materials of the international. scientific-practical conference, 92-94. Ivano-Frankivsk, Ukraine: Ukrainian Scientific-Research Institute of Mountain Forestry] (in Ukrainian)

Козий Г.В. (1950). Четвертичная история Восточно-Карпатских лесов: автореф. дис. ... д-ра биолог. наук / Львовский научно-природоведческий музей AH УССР, Львов. [Kozyi, H. V. (1950) Quaternary history of the East Carpathian forests: doctoral dissertation abstract. Lviv Museum of Natural History of the Academy of Sciences of the Ukrainian SSR, Lviv, Ukraine] (in Russian)

Комендар B. I. (1957). До питань про динаміку рослинних поясів у Східних Карпатах Український ботанічний журнал, 14(4), 15-25 [Komendar, V.I. (1957). To the questions about dynamic of plant belts in the Eastern Carpathians. Ukrainian Botanical Journal, 14(4), 15-25] (in Ukrainian)

Король М. М., Горошко М. П. (2000). Видове число та його зв' язок з іншими об' ємоутворюючими показниками. Науковий вісник національного аграрного yн-my, 25, 351-356. [Korol, M.M., \& Horoshko, M.P. (2000). Species number and its relation with other volumeforming indicators. Scientific Bulletin of National Agrarian University, 25, 351-356] (in Ukrainian)

Котов М.И., Чопик В.И. (1960). Основные черты флоры и растительности Украинских Карпат. Флора и фауна Kapnam. Москва: Изд-во АН CCCP, 3-33. [Kotov, M. Y., \& Chopyk, V.Y. (1960). The main features of the flora and vegetation of the Ukrainian Carpathians. In Flora and Fauna of the Carpathians (pp. 3-33). Moscow: Publishing House of the USSR Academy of Sciences] (in Russian)
Методика визначення належності лісових територій до пралісів, квазіпралісів і природних лісів (2018). Затверджено наказом № 161 від 18.05.2018 р. Київ: Міністерство екології та природних ресурсів України. 8 с. [Methods for determining the affiliation of forest areas to virgin, quasi-virgin and natural forests (2018). Approved by Order № 161 of May 18, 2018. Kyiv: Ministry of Ecology and Natural Resources of Ukraine] (in Ukrainian)

Миклуш С.I., Горошко М.П., Часковський О.Г. (2006). Геоінформаційні системи в лісовому господарстві. Львів: НЛТУ України. 128 с. ISBN 5-7763-0180-7. [Myklush, S.I., Horoshko, M.P., \& Chastkovskyi, O.H. (2006). Geographic information systems in Forestry. Lviv: Ukrainian National Forestry University] (in Ukrainian)

Парпан В.І., Стойко С.М. (1999). Букові праліси Українських Карпат: їх охорона i ценотична структура. Наукові записки УкрНДІгірліс, 4, 81-86. [Parpan, V. I, Stoyko, S. M. (1999). Beech virgin forests of the Ukrainian Carpathians: their protection and coenotic structure. Scientific notes of Ukrainian Scientific-Research Institute of Mountain Forestry, 4, 81-86] (in Ukrainian)

Парпан В.I., Стойко С.М., Парпан Т.В. (2013). Екологічна та фітоценотична характеристики Fageta sylvaticae України: можливості розширення їхньої площі в контексті глобального потепління. Украӥнський ботанічний журнал, 70(3), 361368. [Parpan, V.I., Stojko, S. M., \& Parpan, T. V. (2013). Ecological and phytocoenotical characteristics of Fagetae sylvaticae of Ukraine and possibility to expand their areas due to global warming. Ukrainian Botanical Journal, 70(3), 361-368. Retrieved from file://C:/Users/User/ Downloads/UBJ_2013_70_3_14.pdf] (in Ukrainian)

Парпан В.І., Шпарик Ю.С., Лосюк В.П. (2003). Моніторинг лісів Косівського району. Екологометодичні проблеми Гуиульщчини: матеріали четвертої регіональної наук.-практ. конф. 39-43. Косів: НПП «Гуцульщина». [Parpan, V.I., Shparyk, Yu. S., \& Losiuk, V.P. (2003). Monitoring of forests of Kosiv district. In Ecological and methodological problems of Hutsulshchyna, 39-43. Kosiv, Ukraine: Hutsul National Nature Park] (in Ukrainian)

Парпан В.І., Шпарик Ю.С., Парпан Т.В. (2006). Перспективи розвитку гірського лісівництва. Лісовий $і$ мисливський журнал, 4, 18-19. [Parpan, V.I., Shparyk, Yu. S., \& Parpan, T. V. (2006). Perspectives of the development of mountain forestry Forest and hunting magazine, 4, 18-19] (in Ukrainian)

Пастернак П.С. (1961). Типы еловых лесов. Tunbl горных лесов. Ужгород: Карпати. С. 54-63. [Pasternak, P.S. (1961). Types of spruce forests. In Types of mountain Forests (pp. 54-63). Uzhgorod: Karpaty] (in Ukrainian)

Стойко С. М. (2018). Екологія, ценотична гетерогенність формації бука лісового в Україні та збереження пралісових екосистем. Наукові праці Лісівничої академї наук Украӥни, 17, 149-157. [Stoyko, S. (2018). Ecology, coenotic heterogeneity of the forest beech formation in Ukraine and the protec- 
tion of pristine ecosystems. Proceedings of the forestry academy of sciences of Ukraine, 17, 149-157. https://doi. org/10.15421/411830] (in Ukrainian)

Трибун П.А. (1969) Предгорные леса ИваноФранковской области и пути повышения их продуктивности: автореф. дисс. ... канд. с.-х. наук / Харьковский сельскохозяйственный институт, Харьков. [Trybun, P.A. (1969). Foothill forests of IvanoFrankivsk region and ways to increase their productivity: $\mathrm{PhD}$ dissertation abstract. Kharkiv Agricultural Institute, Kharkiv, Ukraine] (in Russian)

Чернявський М. В. (2000). Букові праліси як еталони лісів майбутнього. Дослідження басейнової екосистеми Верхнього Дністра. Львів: Інститут екології Карпат. С. 164-183. [Chernyavsky, M.V. (2000). Beech virgin forests as standards of forests of the future. In Research of the Upper Dniester basin ecosystem (pp. 164-183). Lviv: Institute of Carpathian Ecology] (in Ukrainian)

Шпарик Ю.С., Коммармотт Б., Беркела Ю.Ю. (2010). Структура букового пралісу Украӥнських Kapnam. Снятин: Прут принт. 144 с. [Shparyk, Yu. S., Kommarmott, B., \& Berkela, Yu. Yu. (2010). Structure of beech virgin forest of the Ukrainian Carpathians. Sniatyn: Prut print. Retrieved from http://194.44.152.155/elib/local/3309.pdf] (in Ukrainian)

Шухевич В.О. (2019). Гуцульщина в 5 частинах. (Репринтне видання 1899-1908рр.). Харків: Видавець Олександр Савчук. [Shukhevych, V.O. (2019). Hutsulshchyna in 5 parts. (Reprint edition 1899 1908). Kharkiv: Publisher Oleksandr Savchuk. ISBN 111111-111-128] (in Ukrainian)

Besser W. (1809). Primitiae florae Galiciae austriacae utriusque. Pars 1. Viennae. [Besser, W. (1809). Flora of the Austrian Galicia. Part 1. Vienna] (in Latin)

Brändli, U.-B.; Dowhanytsch, J. (Red.) (2003). Urwälder im Zentrum Europas. Ein Naturführer durch das Karpaten-Biosphärenreservat in der Ukraine. Birmensdorf, Eidgenössische Forschungsanstalt WSL; Rachiw, Karpaten-Biosphärenreservat. Bern, Stuttgart, Wien, Haupt. 192 s. [Brändli, U.-B., Dowhanytsch, J. (Red.) (2003). Primeval Forests in Central Europe. A nature guide to the Carpathian Biosphere Reserve in Ukraine. Birmensdorf, Swiss Federal Research Institute WSL; Rakhiv, Carpathian Biosphere Reserve. Bern, Stuttgart, Vienna, Haupt.] (in Germany)

Flora Polska: rosliny naczyniowe polski i ziem osciennych (1919-1980). Warszaw: Inst. Bot. Pol. Acad. Nauk [Flora of Poland: Polish vascular plants and neighboring lands (1919-1980). Warsaw: Institute of Botany of the Polish Academy of Sciences] (in Polish)

Herbich F. (1865). Przyczynek do geografii roślin w Galicyi. Rocznik Towarzystwa nauk Kraków, 33, 70129. [Herbich, F. (1865). Contribution to plant geography in Galicia. Yearbook of the Society of Sciences Krakow, 33, 70-129] (in Polish)

Jachno, J. (1884). Systematyczny przeglad galicyjskich roślin wedle systemu Linneusza ze szezególowym uwgylednieniem gatunkow rosnących w okolicy miasta Stanislawowa i Kolomyi. Stanislawow. [Jach- no, J. (1884). A systematic overview of Galician plants according to the Linnaeus system with a specific attention to species growing in the outskirts of the cities of Stanisławów and Kolomyia. Stanislawow] (in Polish)

Kontny P. (1937). Z przeszłosci cisa (Taxus baccata L.). Sylwan: Organ Polskego Towarzystwa Lésnego. Rocznik Anneé LV., ser. A., 29-68. [Kontny, P. (1937). Yew from the past (Taxus baccata L.) Sylwan: Organ of the Polish forest Society. Yearbook Anneé LV., ser. $A, 29-68]$ (in Polish)

Kozij G. (1936). Zapiski florystyczne z Karpat Pokuckich. Kosmos, 61, 515-523. [Koziy, G. (1936) Floristic notes from the Pokutski Carpathians. Kosmos, 61, 515523] (in Polish)

Leibundgut H. (1959). Über Zweck und Methodik der Struktur-und Zuwachsanalyse von Urwäldern. Schweiz. Zeitschrift für Forstwesen, 110(3), 111-124. [Leibundgut, H. (1959). About the purpose and methodology of the structure and growth analysis of primeval forests. Switzerland. Journal of Forestry, 110(3), 111-124] (in Germany)

Raciborski M. (1886). Rośliny zebrane przez A. J. Śleńdzińskiego w r. 1880, oznazone przez M Raciborskiego. Spraw. Kom. Fizyjogr, 20, 1-44. [Raciborski, M. (1886). Plants collected by A. J. Śleńdziński in 1880, identificated by M. Raciborski. Physiographic commission's report, 20, 1-44] (in Polish)

Sabatini, F. M., Burrascano, S., Keeton, W.S.,. Levers, Ch., Lindner, M., Pötzschner, F.,.. Kuemmerle, T. (2018). Where are Europe's last primary forests? Divers Distrib., 24, 1426-1439. https://doi. org/10.1111/ddi.12778

Śleńdziński A.J. (1875). Przyczynek do flory obwodu kolomyjskiego. Spraw. Kom. Fizyogr., 9, 49-71. [Śleńdziński, A.J. (1875). Contribution to the flora of the Kolomyia region. Physiographic commission's report, 9, 49-71] (in Polish)

Śleńdziński A.J. (1876). Wykaz roslin zebranych w obwodzie Kolomyjskim w roku 1876. Spraw. Kom. Fizyogr., 10, 91-112. [Śleńdziński, A. J. (1876). List of plants collected in the Kolomyia region in 1876. Physiographic commission's report, 10, 91-112] (in Polish)

Szafer W., Kulczyński S., Pawłowski B. (1924). Rośliny polskie: opisy i klucze do oznaczania wszystkich gatunków roślin naczyniowych rosnących w Polsce bądź dziko, bądź też zdziczałych lub częściej hodowanych. Lwow-Warszawa. [Szafer, W., Kulczyński, S., Pawłowski, B. (1924) Polish plants: descriptions and keys for marking all species of vascular plants growing in Poland either in the wild, or feral or more often bred. Lwiw-Warshawa] (in Polish)

Wajgl L. (1883) Flora miasta Kołomyi i jego okolicy. Spraw. c.k. dyrekcyiwyźn. Gymnaz. w Kołomyi za rok 1882. Kołomyja,. 1-47. [Wajgl L. (1883) Flora of the city of Kołomyja and its surroundings. Report of directorate of the Gymnazia in Kołomyja for 1882. Kołomyja. 1-47] (in Polish)

Wittman N. (1824a). Bemerkungen auf einer botanischen. Raise durch den südostlichen. Theil Gali- 
ziens nach der Bukowina und lands der Karpatischen Bergstrasse. (Im Jahre, 1823). Mnemosyne, 45-46, 50-51, 58-59, 62, 68, 75-76, 83-84. [Wittman, N. (1824a). Notes of a botanical. Raise through the southeast part of Galicia to Bukovina and lands of the Carpathian Mountain Road. (in 1823). Mnemosyne, 45-46, 50-51, 58$59,62,68,75-76,83-84]$ ( in German)

Wittman N. (1824b). Spostrezenie w podrozy podjętej we względzie botanicznym r. 1823 przez poludniowąwschodnią czesc Galicyi do Bukowiny i drogą pod Karpaty idąca. Rozmaitoşci, 137-140, 145-150. [Wittman, N. (1824b). Summary trip taken in botanical terms in 1823 in the south-eastern part of Galicia to Bukovina and the road nearby Carpathians. Variety, 137-140, 145-150] (in Polish)

Wołoszczak E. (1888). Przyczynek do flory Pokucia. Spraw. Kom. Fizyogr., 21, 111-139. [Wołoszczak, E. (1888). Contribution to the flora of Pokuttya. Physiographic commission's report, 21, 111-139] (in Polish)

Wróblewski A. (1917). Kilka rzadszych roślin Pokucia i Wołynia galicyjskiego. Spraw. Kom. Fizyogr., 51, 89-99. [Wróblewski, A. (1917). Several rare plants of Pokuttya and Volyn Galician. Physiographic commission's report, 51, 89-99] (in Polish)

Zawadski A. (1835). Enumeracio Plantarum Galiciae und Bucovinie oder die in Galicien und der Bucovina wildwachsenden Pflanzen. Breslau, 24, 200. [Zawadski, A. (1835). Enumeracio Plantarum Galiciae et Bucovinie or the plants that grow wild in Galicia and Bucovina. Breslau, 24, 200] (in German)

\section{State and structure of the natural spruce forests in the Pokuttia Carpathians}

\author{
V. Losyuk ${ }^{1}$, O. Pohribnyi ${ }^{2}$, M. Tomych ${ }^{3}$, \\ O. Chaskovskyy ${ }^{4}$, P. Vandzhurak ${ }^{5}$, lu. Debryniuk ${ }^{6}$
}

The Pokuttia Carpathians are located in the southeastern part of the northern mega-slope of the Ukrainian Carpathians, covering an area of 659.7 square $\mathrm{km}$, which is about $3 \%$ of the Ukrainian Carpathians area. The forest area of the Pokuttia Carpathians is 39.1 thousand hectares, including 8.2 thousand hectares of the natural spruce forests or $21 \%$ of the forests of study region. The forests of the Pokuttia Carpathians where studied in the framework of the WWF-Ukraine project «The identification of the virgin forest of the Ukrainian Carpathians» to identify their belonging to virgin, quasi-virgin and natural spruce groups of protected forests. The main assessment characteristics and the successions dynamics in the spruce forests are analyzed based on the example of a permanent research plot in the spruce forest. Its characteristics are very close to the virgin forest in the conditions of moist pure highland spruce forests. The studied natural forest corresponds to almost all the features of spruce virgin forests, except the area (less than 20 hectares).
The field studies were conducted since 2010 with five-year intervals in accordance with the method of second level environmental monitoring under the program "ISR-Forest". The assessment results on the condition and structure of natural spruce communities of the Pokuttia Carpathians are presented in the paper. An interactive map of the virgin and quasi-virgin forests distribution at the study area has been developed.

The dynamics of the quantitative characteristics of natural spruce stands over the past 10 years indicates a little rate of the total number of trees decreasing. During 2015-2020 there was a significant increase of the spruce-trees number in the second layer, while the number of trees in the third layer is consistently low. The number of live trees of the first tier during the 10year observation period decreased significantly (by almost 24\%). The trees are located in the stand as a biogroups. The crowns in the biogroups ranges from 0.8 to 1 . Forest herbaceous species (34 species) form a fairly dense cover. Their projective cover is $85 \%$ in the presence of more than 30 species. At the same time, the processes of vegetation transformation in natural spruce ecosystems are observed. The recent monitoring shows some decreasing of the indices at the category of condition, vitality, marketability and crown length of spruce trees and increasing of the indices at the category deadwood volume and variety of damages (compared to 2010). The reason is, first of all, in climate change. Spruce forests very sensitive to such changes. The study of the state and structure of natural spruce forests

Vasyl Losyuk - Corresponding Member of the Forestry Academy of Sciences of Ukraine, $\mathrm{PhD}$ in Agricultural Sciences, Researcher. National Nature Park "Hutsulshchyna", Druzhba str., 84, Kosiv, Ivano-Frankivsk region, 78600, Ukraine. Tel.: + 03478-23709. E-mail: losyuk@i.ua ORCID: https://orcid.org/0000-0003-18071264

Oleh Pohribnyi - PhD in Agricultural Sciences, Head of the Scientific Research Department. National Nature Park "Hutsulshchyna", Druzhba str., 84, Kosiv, Ivano-Frankivsk region, 78600, Ukraine. Tel.: + 03478-23709. E-mail: pogribnyj@i.ua ORCID: https:// orcid.org/0000-0002-8428-6514

Maria Tomych - PhD in Biological Sciences, Headofthe Laboratory of Environmental Monitoring. National Nature Park "Hutsulshchyna", Druzhba str., 84, Kosiv, Ivano-Frankivsk region, 78600, Ukraine. Tel.: + 03478-23709. Email: maritom82@ukr.net ORCID: https://orcid.org/0000-0002-7274-3618

4 Oleh Chaskovskyy - Corresponding Member of the Forestry Academy of Sciences of Ukraine, PhD in Agricultural Sciences, Associate Professor of the Department of forestry management and inventory. Ukrainian National Forestry University, General Chuprynka str., 103, Lviv, 79057, Ukraine. Tel.: + 0322-378094. E-mail: oleh.chaskov@googlemail.com ORCID: https://orcid. org/0000-0003-0361-0624 Scopus ID: 26323447500

Pavlo Vandzhurak - PhD candidate. Ukrainian National Forestry University, General Chuprynka str., 103, Lviv, 79057, Ukraine. Tel.: +0322-37-80-94. E-mail: pavlov.76@ukr.net

$6 \quad$ Iurii Debryniuk - Full Member of the Forestry Academy of Sciences of Ukraine, Academician-Secretary of the FASU, Doctor of Agricultural Sciences, Professor of the Department of Forest Crops and Forest Selection. Ukrainian National Forestry University, General Chuprynka str., 103, Lviv, 79057, Ukraine. Tel.: 032-235-30-12,+38-067-195-78-36. E-mail: debrynuk_ju@ ukr.net ORCID: https://orcid.org/0000-0002-0994-349X 
in the Pokuttia Carpathians in the dynamics provides an opportunity to foresee the future developments of spruce virgin and quasi-virgin forests in the Ukrainian Carpathians.

Key words: forest fund; spruce natural forest; stand; dead wood; natural recovery; grass cover; virgin; quasi-virgin.

\section{Состояние и структура природных еловых лесов Покутских Карпат}

\author{
В.П. Лосюк' ${ }^{1}$ О.О. Погрибный², \\ М. В. Томыч ${ }^{3}$, О.Г. Часковский ${ }^{4}$, П.И. Ванджурак ${ }^{5}$, \\ Ю.М. Дебрынюк ${ }^{6}$
}

Покутские Карпаты расположены в юговосточной части северного мегасклона Украинский Карпат, занимая площадь 659,7 км² $^{2}$, что составляет около 3\% площади Украинских Карпат. Площадь лесов Покутских Карпат составляет 39,1 тыс. га, из них доля природных еловых древостоев - 8,2 тыс. га или $21 \%$ площади лесов исследуемого региона. Согласно проекта WWF-Украина «Идентификация лесов Украинских Карпат», обследованы леса Покутских Карпат для определения принадлежности лесных территорий к девственным, квазидевственным и природным еловым лесам. Основные таксационные характеристики и динамика сукцессий еловых древостоев проанализированы на примере постоянной пробной площади, заложенной в еловом природном лесу, по своим характеристикам очень близкому к девственным лесам, в условиях влажной чистой высокогорной сурамени. Исследуемый природный лес отвечает практически всем признакам елового девственного леса, за исключением площади $(<20$ га).

Полевые исследования осуществлены с 2010 г. с пятилетним интервалом в соответствии с методикой экологического мониторинга II уровня по программе «CP-Forest». Приведены результаты оценки состояния и структуры природных еловых лесов Покутских Карпат. Создано интерактивную карту распространения девственных и квазидевственных лесов исследуемой территории.

Природные еловые леса занимают высокие хребты и вершины среднегорья Покутских Карпат на высотах 900-1400 м над уровнем моря и выполняют, прежде всего, противоэрозионные, водорегулирующие, почвозащитные и другие важные функции. Они характеризуется следующими показателями: высоким количеством деревьев и высоким запасом стволовой древесины; значительным запасом мертвой лежащей древесины; близкой к средней жизненностью деревьев и высокой их товарностью; достаточным количеством подроста низших высотных групп и недостаточным - высших; незначительным антропогенным воздействием.

Динамика количественных характеристик природного елового древостоя за последние 10 лет сви- детельствует о некотором уменьшении общего количества деревьев. В течение 2015-2020 гг. отмечено значительное увеличение особей ели во втором ярусе, тогда как в третьем ярусе количество деревьев стабильно низкая. Количество живых деревьев первого яруса в течение 10-летнего периода наблюдений существенно снизилось (почти на 24\%). Расположение деревьев в древостое имеет групповой характер, сомкнутость крон варьирует в пределах 0,8-1,0. Лесные травяные виды формируют достаточно плотный покров, проективное покрытие которого составляет $85 \%$ при наличии более 30 видов. Наряду с этим, обнаружены процессы трансформации растительного покрова в девственных лесах. Последние мониторинговые исследования выявили некоторое снижение показателей категории состояния, жизненности, товарности, длины кроны у деревьев ели европейской, увеличение объема сухостоя и видов повреждений по сравнению с 2010 годом. Причина заключается, прежде всего, в климатических изменениях, на которые еловые леса реагируют особенно ощутимо.

Ключевые слова: Украинские Карпаты; древостой; мертвая лежащая древесина; естественное возобновление; травяной покров; девственный лес; квазидевственный лес.

Лосюк Василий Петрович - член-корреспондент Лесной академии наук Украины, кандидат сельскохозяйственных наук, научный сотрудник. Национальный природный парк «Гуцульщина», ул. Дружбы, 84, г. Косов, Ивано-Франковская обл., 78600, Украина. Тел.: +034-78-23-709. E-mail: losyuk@i. ua ORCID: https://orcid.org/0000-0003-1807-1264

Погрибный Олег Олегович - кандидат сельскохозяйственных наук, начальник научного отдела. Национальный природный парк «Гуцульщина», ул. Дружбы, 84, г. Косов, ИваноФранковская обл., 78600, Украина. Тел.: +034-78-23-709. E-mail: pogribnyj@i.ua ORCID: https://orcid.org/0000-00028428-6514

Томыч Мария Васильевна - кандидат биологических наук, начальник лаборатории экологического мониторинга. Национальный природный парк «Гуцульщина», ул. Дружби, 84, г. Косов, Ивано-Франковская обл., 78600, Украина. Тел.: +03478-23-709. E-mail: maritom82@ukr.net ORCID: https://orcid. org/0000-0002-7274-3618

4 Часковский Олег Григорьевич - член-корреспондент Лесной академии наук Украины, кандидат сельскохозяйственных наук, доцент кафедры лесной таксации и лесоустройства. Национальный лесотехнический университет Украины, ул. генерала Чупринки, 103, г. Львов, 79057, Украина. Тел.:+032237-80-94. E-mail: oleh.chaskov@googlemail.com ORCID: https://orcid.org/0000-0003-0361-0624 Scopus ID: 26323447500

Ванджурак Павел Иванович - соискатель научной ступени кандидата сельскохозяйственных наук. Национальный лесотехнический университет Украины, ул. генерала Чупринки, 103, г. Львов 79057, Украина. Тел.: +0322-378094. E-mail: pavlov.76@ukr.net

6 Дебрынюк Юрий Михайлович - академик Лесной академии наук Украины, академик-секретарь ЛАН Украины, доктор сельскохозяйственных наук, профессор кафедры лесных культур и лесной селекции. Национальный лесотехнический университет Украины, ул. Генерала Чупринки, 103, г. Львов, 79057, Украина. Тел.: 032-235-30-12, +38-067-195-78-36. E-mail: debrynuk_ju@ukr.net ORCID: http://orcid.org/0000-0002-0994$349 \mathrm{X}$ 